\title{
Air quality in the mid-21st century for the city of Paris under two climate scenarios; from the regional to local scale
}

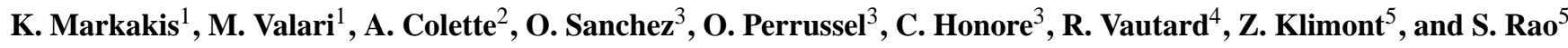 \\ ${ }^{1}$ Laboratoire de Meteorologie Dynamique, IPSL Laboratoire CEA/CNRS/UVSQ, Ecole Polytechnique, 91128 Palaiseau \\ CEDEX, France \\ ${ }^{2}$ Institut national de l'environnement industriel et des risques (INERIS), Paris, France \\ ${ }^{3}$ AIRPARIF, Assosciation de surveillance de qualite de l'air en Île-de-France, 7 rue Crillon, 75004, Paris, France \\ ${ }^{4}$ Laboratoire des Sciences du Climat et de l'Environnement, IPSL Laboratoire CEA/CNRS/UVSQ, Orme des Merisiers, \\ $91191 \mathrm{Gif} /$ Yvette CEDEX, France \\ ${ }^{5}$ International Institute for Applied Systems Analysis, Schlossplatz 1, 2361, Laxenburg, Austria
}

Correspondence to: K. Markakis (konstantinos.markakis@1md.polytechnique.fr)

Received: 29 November 2013 - Published in Atmos. Chem. Phys. Discuss.: 6 January 2014

Revised: 5 June 2014 - Accepted: 9 June 2014 - Published: 17 July 2014

\begin{abstract}
Ozone and $\mathrm{PM}_{2.5}$ concentrations over the city of Paris are modeled with the CHIMERE air-quality model at $4 \mathrm{~km} \times 4 \mathrm{~km}$ horizontal resolution for two future emission scenarios. A high-resolution $(1 \mathrm{~km} \times 1 \mathrm{~km})$ emission projection until 2020 for the greater Paris region is developed by local experts (AIRPARIF) and is further extended to year 2050 based on regional-scale emission projections developed by the Global Energy Assessment. Model evaluation is performed based on a 10-year control simulation. Ozone is in very good agreement with measurements while $\mathrm{PM}_{2.5}$ is underestimated by $20 \%$ over the urban area mainly due to a large wet bias in wintertime precipitation. A significant increase of maximum ozone relative to present-day levels over Paris is modeled under the "business-as-usual" scenario $(+7 \mathrm{ppb})$ while a more optimistic "mitigation" scenario leads to a moderate ozone decrease $(-3.5 \mathrm{ppb})$ in year 2050 . These results are substantially different to previous regionalscale projections where 2050 ozone is found to decrease under both future scenarios. A sensitivity analysis showed that this difference is due to the fact that ozone formation over Paris at the current urban-scale study is driven by volatile organic compound (VOC)-limited chemistry, whereas at the regional-scale ozone formation occurs under $\mathrm{NO}_{\mathrm{x}}$-sensitive conditions. This explains why the sharp $\mathrm{NO}_{\mathrm{x}}$ reductions implemented in the future scenarios have a different effect on ozone projections at different scales. In rural areas, projections at both scales yield similar results showing that the
\end{abstract}

longer timescale processes of emission transport and ozone formation are less sensitive to model resolution. $\mathrm{PM}_{2.5}$ concentrations decrease by $78 \%$ and $89 \%$ under business-asusual and mitigation scenarios, respectively, compared to the present-day period. The reduction is much more prominent over the urban part of the domain due to the effective reductions of road transport and residential emissions resulting in the smoothing of the large urban increment modeled in the control simulation.

\section{Introduction}

Climate change can affect air quality through a number of mechanisms related to meteorological variables such as temperature, humidity, precipitation, solar radiation, wind speed and the planetary boundary layer height. If the effects of atmospheric pollutants (greenhouse gasses, other gaseous species and aerosols) on climate change have been extensively investigated over the last decades (IPCC, 2001, 2007) the impact of these emissions and changed climate on air quality has only raised interest during the last few years and many issues remain open. Most of these studies use global chemistry transport models (CTMs) to study the impact of changing climate on tropospheric ozone at either the global (Brasseur et al., 1998; Liao et al., 2006; Prather et al., 2003; Szopa and Hauglustaine, 2007) or regional scale (Murazaki 
and Hess, 2006; Szopa et al., 2006). The resolution of these studies, typically a few hundreds of kilometers, is insufficient to capture the high spatial variability of air pollution due to the short lifetime of tropospheric ozone and particulate matter (in the range of some hours up to a few days) (Seinfeld and Pandis, 2006), as well as to the sharp horizontal gradients of anthropogenic emissions over urban areas. Moreover, the climate-chemistry models used in such large-scale studies suffer from a simplistic representation of regional-scale chemistry.

Only few, recent applications study the impact of changing climate on air quality using regional CTMs. These models include more sophisticated chemistry at typical resolutions of tenths of kilometers and therefore provide a better understanding of the underlying mechanisms at the regional scale. The first documented modeling study on the impact of future conditions at the regional scale is that of Hogrefe et al. (2004) while at the same time Knowlton et al. (2004) took a step forward and performed a health impact assessment study for the greater New York region. Since then, several researchers have performed similar regional applications in order to derive future predictions of ozone and/or aerosols using offline climate-chemistry models (Colette et al., 2013; Huszar et al., 2011; Katragkou et al., 2011; Kelly et al., 2012; Lam et al., 2011; Langner et al., 2005; Nolte et al., 2008; Steiner et al., 2006; Szopa and Hauglustaine, 2007; Tagaris et al., 2009), online climate-chemistry models (Forkel and Knoche, 2006, 2007) or multi-model studies (Colette et al., 2012; Langner et al., 2012).

A current research challenge is the impact of climate change on air quality at the urban scale. Enhanced health effects due to increasing urbanization (UNFPA, 2007) should be addressed primarily at such scale especially given that the efforts to mitigate air pollution are more intense in areas where the largest health benefits are observed (Riahi et al., 2011). The common approach to study the effects of climate change and emissions at city level is to use regional-scale CTMs. However the resolution of current model studies remains too coarse to represent the high spatiotemporal variability of pollutants at the urban scale. Regional-scale emission inventories fail to represent the plethora of emission activities in terms of, for example, the underlying technologies used within a specific source sector, or fail to take into account the habitual patterns of the population at large cities (Markakis et al., 2010, 2012). The substantial part of the published work uses emission projections based on scenarios developed to represent changes at the global scale and are rarely well suited for local-scale assessment, e.g., they lack the detailed representation of all emission activities at a finer scale. For example, the more recent Representative Concentration Pathways (RCPs) (van Vuuren et al., 2011) developed to support modeling activities for the new assessment of the Intergovernmental Panel on Climate Change (IPCC) incorporate a diversity of radiative forcing scenarios that may be suitable for large-scale climate-chemistry models but not ap- propriate to represent emission trends for specific cities and therefore regional-scale air-quality assessment (Butler et al., 2012). Grid resolution is another key issue for urban-scale modeling as shown by previous research (Arunachalam et al., 2006; Cohan et al., 2006; Valari and Menut, 2008). The assumption of instantaneous mixing of emissions within the volume of the regional-scale CTMs' grid cells is unsuitable to represent local-scale chemistry (such as ozone titration) when the grid-cell size is too large compared to the actual size of the emitting areas. It has been shown previously that use of coarse resolution leads to underprediction of daily ozone maxima and to overprediction of daily average ozone levels (Arunachalam et al., 2006; Tie et al., 2010; Vautard et al., 2007). Valin et al. (2011) show that grid resolution finer than $\sim 10 \mathrm{~km}$ is often necessary to capture ozone chemistry near areas with large $\mathrm{NO}_{\mathrm{x}}$ emissions. Due to the non-linearity of ozone chemistry the inability of large grid sizes to differentiate urban and rural areas can have a profound effect on the simulated ozone concentrations (Silman et al., 1990). Forkel and Knoche (2007) found that the increase of future maximum ozone concentrations in Europe occurred in areas where high mixing ratios of $\mathrm{NO}_{\mathrm{x}}$ coincided with increased isoprene emissions, indicating that the failure of coarser resolutions to efficiently distinguish between urban and rural areas would result in overestimation of future ozone in cities near high isoprene emitting sources. The current challenge is to develop realistic long-term emission projections at a cityscale and bridge the gap between local-, regional- and globalscale modeling.

The aim of our study is to develop mid-21st century horizon air-quality projections over the greater Paris area under two consistent emission and climate scenarios (10-year continuous simulation). To the authors knowledge, this is the first time where a 10-year air-quality projection under climate and city-level emission changes has been conducted at an urban scale and with a resolution as fine as $4 \mathrm{~km}$. Local emission projections used in this study are compiled by merging several pieces of information: (i) a high-resolution (i.e., $1 \mathrm{~km}$ ) city-specific emission inventory developed by AIRPARIF (present-day emissions); (ii) a city-scale short-term projection (until 2020) considering air-quality policies already in place and planned for the city for the next years (iii) two mid-21st century regional-scale emission scenarios including both climate and regional air-quality policies developed by the Global Energy Assessment (GEA) (Riahi et al., 2012). The "reference" (REF) scenario is consistent with long-term climate outcomes of the RCP-8.5 adopting all current and planned air-quality legislation until 2030, and assumes that no climate policies are implemented thereafter. The "mitigation" (MIT) scenario is consistent with long-term climate outcomes of the RCP-2.6 and additionally assumes stringent climate mitigation policies. The final fine-scale, mid21 st horizon emission inventory for the greater Paris area, the Ile-de-France region (IdF), was obtained by scaling the 


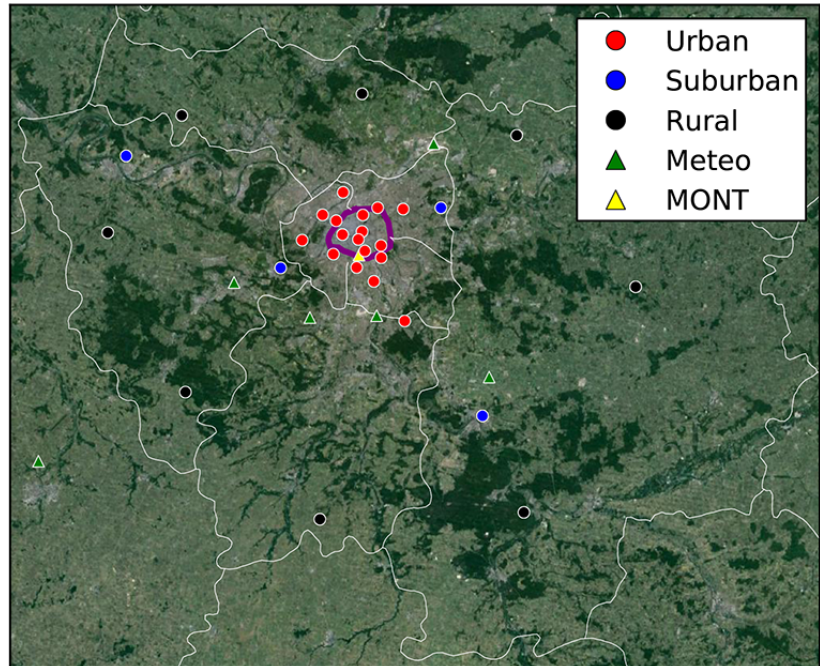

Figure 1. Local-scale (IdF) simulation domain, with the city of Paris in the center (area enclosed in the purple line). Circles correspond to sites of the local air-quality monitoring network (AIRPARIF) with red for urban, blue for suburban and black for rural. Triangles correspond to the meteorological stations (the yellow triangle correspond to the Montsouris station located in the city center).

2020 high-resolution emission inventory to the year 2050 using the regional-scale GEA scenarios.

After describing the methodology in Sect. 2, an evaluation of the modeling system is described in Sect. 3 and scenario results are presented in Sect. 4. Our conclusions are discussed in Sect. 5.

\section{Materials and methods}

The Ile-de-France region (IdF) is located at $1.25-3.58^{\circ} \mathrm{E}$ and $47.89-49.45^{\circ} \mathrm{N}$ with a population of approximately $11.7 \mathrm{mil}-$ lion, more than two million of which live in the city of Paris (Fig. 1). The area is situated away from the coast and is characterized by uniform and low topography, not exceeding 200 m a.s.l.

An "offline" modeling approach is used to assess air quality in the study region as a response to climate and emission changes. For both climate and air-quality simulations we use a dynamical downscaling approach consisting of two oneway nesting steps: from the global to regional scale over Europe and from the regional to local scale over the IdF region. The IPSL-CM5A-MR global circulation model (Dufresne et al., 2013) is used to derive future projections of the main climate drivers (temperature, solar radiation, etc.) using a set of available global greenhouse gas emission scenarios (RCP-2.6 and RCP-8.5).

Global climate output is downscaled with the weather research and forecasting (WRF) mesoscale climate model (Skamarock and Klemp, 2008) at two steps: first over a $50 \mathrm{~km}$ resolution grid over Europe and then on a $10 \mathrm{~km}$ resolution grid over France using one-way nesting. We drive the CTM over IdF using the $10 \mathrm{~km}$ meteorology acknowledging both the computation overhead of a refined meteorology and the results of previous work over the same region using the CHIMERE CTM (Menut et al., 2005a; Valari and Menut., 2008). More specifically, Menut et al. (2005a) showed that apart from the coastal areas where a refined meteorology improved air-quality modeling results, in the rest of France ozone peaks were better captured with lower-resolution meteorological input. Valari and Menut (2008) showed that a refined meteorological input gives similar results for ozone and that model performance is much more sensitive to the resolution of emissions than to meteorology. These results suggest that in areas that have the same geographical characteristics of the greater Paris area (flat topography at great distance from any mountains or the ocean) increasing the resolution of the meteorological input does not necessarily improve the results of the chemical transport modeling. On the other hand Flagg and Taylor (2011) investigated the impact of the resolution of the surface layer input data on modeling results of high-resolution simulations in an urban coastal environment and found that these results were quite dependent on that resolution. There are indications that one needs to go to very-high-resolution in order to capture the urban heat island circulation (LeRoyer et al. 2014) and the effects of the surface layer changes (Flagg and Taylor, 2008) in an urban meteorological simulation, but this analysis is beyond the scope of the present work.

Air-quality data are downscaled with the CHIMERE model (Menut et al., 2013) a detailed description of which can be found at: http://www.lmd.polytechnique.fr/chimere. CHIMERE is an offline chemical transport model (CTM), which models atmospheric chemistry and transport, forced by anthropogenic emissions, biogenic emissions, a meteorological simulation and boundary conditions. It is a cartesianmesh grid model including gas-phase, solid-phase and aqueous chemistry, biogenic emissions modeling dependant on meteorology with MEGAN (Model of Emissions of Gases and Aerosols from Nature) (Guenther et al., 2006), dust emissions (Menut et al., 2005b) and resuspension (Vautard et al., 2005). Gas-phase chemistry is based on the MELCHIOR mechanism (Lattuati, 1997) which includes more than 300 reactions of 80 gaseous species. The aerosols model species are sulfates, nitrates, ammonium, organic and black carbon and sea salt (Bessagnet et al., 2010) and the gas-particle partitioning of the ensemble sulfate/nitrate/ammonium is treated by the ISORROPIA code (Nenes et al., 1998) implemented online in CHIMERE.

Initial and boundary conditions are taken from globalscale concentrations modeled with the coupled LMDz-INCA global chemistry model (Hauglustaine et al., 2004; Szopa et al., 2013) and are then downscaled with CHIMERE using two-level one-way nesting first at a $0.5^{\circ}$ resolution grid $(\sim 50 \mathrm{~km})$ over Europe (Colette et al., 2013$)$ and then at the 
$4 \mathrm{~km}$ resolution grid over the IdF region (local-scale runs). While the nesting step is considered larger than normal, we stress that the main focus of the paper is to investigate the response of the model to the emission reductions at the local scale at a mid-21st century horizon, reductions that appear to be very strong. We show with a sensitivity to chemical regimes that local emissions is a key factor for the observed modeled changes. The nesting step from a coarse resolution of $30 \mathrm{~km}$ or $50 \mathrm{~km}$ to a few $\mathrm{km}$ in the local scale is commonly used with CHIMERE (Beekman and Derognat, 2003; Deguillaume et al., 2008; Valari and Menut, 2008; Valari et al., 2011; Vautard et al., 2001, 2007). For more details on the global and regional modeling exercises the reader is referred to Hauglustaine et al. (2014) and Colette et al. (2013), respectively. We only note that the global-scale simulations done with the LMDz-INCA model has a slightly different chemical speciation from that of CHIMERE. Finally, Table 1 presents the basic configuration of the global, regional and local simulations used in the present study.

We performed three sets of 10-year runs at the local scale: a continuous control run (CTL) from 1995 to 2004 representing present-day air quality and two continuous runs over the 2045-2054 decade representing air-quality projections to the mid-21st century horizon under two different pathways of climate and emissions. To minimize the effect of inter-annual variability and increase the statistical significance of model output, longer-term simulations should have been performed. However, given the high-resolution of the modeling exercise the computational cost of longer simulations was considered too high for the present study.

\section{Models setup}

The modeling domain has a horizontal resolution of $4 \mathrm{~km}$ and consists of 39 grid cells in the west-east direction and 32 grid cells in the north-south direction, thus covering a total region of $156 \times 128 \mathrm{~km}^{2}$. Twelve $\sigma$-p hybrid vertical layers were used to represent the atmospheric column from the surface up to approximately $500 \mathrm{hPa}(\sim 5.5 \mathrm{~km})$ with the thickness of the first layer being $8 \mathrm{~m}$. Simulations were performed with a time step of $5 \mathrm{~min}$. Hourly meteorological fields necessary for CHIMERE were modeled with WRF model v3.4. Weather research and forecasting simulations were carried out on a $10 \mathrm{~km}$ resolution grid of $90 \times 85$ cells. Vertically, the domain is divided into $31 \sigma$-layers extending up to $55 \mathrm{hPa}$ $(\sim 20 \mathrm{~km})$. The time integration step was set to $1 \mathrm{~min}$. The physical options used for these simulations are the WRF Single Moment 6-class microphysics scheme (Hong and Lim, 2006), RRTM (rapid radiative transfer model) long-wave radiation scheme (Mlawer et al., 1997), Dudhia shortwave radiation scheme (Dudhia, 1989), NOAH land surface model (Chen and Dudhia, 2001), Asymmetric Convective Model version 2 Planetary Boundary Layer scheme (Pleim, 2007) and Kain-Fritsch cumulus parameterization scheme (Kain, 2004).

\section{Data and metrics for model evaluation}

CHIMERE model evaluation has been performed in numerous studies at both regional (see, for example, Solazzo et al., 2013a, 2013b and references therein) and urban scales (Hodzic et al., 2005; Vautard et al., 2007). However, due to the climate component of the study, our modeling setup requires a different evaluation framework. We use 29 surface monitors of the local air-quality network AIRPARIF classified as urban (17 sites), suburban (4 sites) and rural (8 sites). Only monitoring sites with more than $70 \%$ of available data (hourly values) through the 10 -year period were considered for the evaluation process. Observations are conducted at a height ranging from 3 to $8 \mathrm{~m}$ from the surface, which makes the first model layer concentrations directly comparable with the observations.

Given that adverse health impact is mainly correlated to daytime ozone levels, in the present framework we focus on the evaluation of daytime and maximum ozone only. A variety of metrics are used to evaluate model performance. For ozone, the widely used mean normalized bias (MNB) and mean normalized gross error (MNGE) are estimated. The US EPA suggests that MNB for modeled ozone concentrations should lie within the $\pm 15 \%$ range and MNGE not exceeding $35 \%$. Regarding $\mathrm{PM}_{2.5}$ the mean fractional bias (MFB) and the mean fractional error (MFE) are used. A literature review of targeted range of values for fine particles can be found in EPA (2007). The narrowest of the reported ranges suggests that for modeled $\mathrm{PM}_{2.5}$ MFB should fall within the $\pm 30 \%$ range and MFE not exceeding $50 \%$.

We extract these metrics from the daytime concentrations values and not the decade average, bearing in mind that this is not typical for runs forced by climate simulations but more suitable for operational forecast evaluation. Here we do not use re-analyses to force the regional CTM but global and regional climate simulations. Consequently, one should expect lower scores than those yielded by an air-quality forecast simulation, especially in the presence of climate biases (Colette et al., 2013; Menut et al., 2013). Since this work is original in its concept, we aim to evaluate whether the urbanscale setup is sufficiently realistic, but utilizing metrics that are timely averaged on a scale finer than a climatological one.

\section{Climate and emission scenarios}

Two long-term scenarios are used in the global-scale simulations of future climate conditions: RCP-8.5 and RCP-2.6. RCP-8.5 (Riahi et al., 2011) is a reference-type scenario with no mitigation for greenhouse gases leading to a global radiative forcing of $8.5 \mathrm{~W} \mathrm{~m}^{-2}$ by the end of the century. RCP-2.6 (van Vuuren et al., 2011a) leads to a global radiative forcing 
Table 1. Configuration description of the global, regional and local simulations of the present study.

\begin{tabular}{llll}
\hline & Global $^{\mathrm{a}}$ & Regional $^{\mathrm{b}}$ & Local $^{\circ}$ \\
\hline GCM/CTM & LMDz-INCA & CHIMERE & CHIMERE \\
Horizontal & $1.9^{\circ} \times 3.75^{\circ}$ & $0.5^{\circ} \times 0.5^{\circ}$ & $4 \mathrm{~km} \times 4 \mathrm{~km}$ \\
$\begin{array}{l}\text { Anthropogenic } \\
\text { emissions (present) }\end{array}$ & RCP & GEA & AIRPARIF \\
$\begin{array}{l}\text { Anthropogenic } \\
\text { emissions scenarios }\end{array}$ & RCP-2.6 $/$ RCP-4.5 & MIT / REF & \\
$\begin{array}{l}\text { Climate model } \\
\text { Resolution }\end{array}$ & IPSL-CM5A-MR & WRF & MIT/REF consistent \\
Climate scenarios & $2.5^{\circ} \times 1.26^{\circ}$ & $0.5^{\circ}$ & WRF \\
\hline
\end{tabular}

\footnotetext{
${ }^{\text {a }}$ For details see Hauglustaine et al. (2014).

${ }^{\mathrm{b}}$ For details see Colette et al. (2013).

c Description given in Sect. 2.3 .

${ }^{\mathrm{d}}$ The mitigation (MIT) and the reference (REF) anthropogenic emission scenarios were developed to be consistent with RCP-2.6 and RCP-4.5, respectively.

$\mathrm{e}$ The future emissions of the local-scale simulations are developed based on a hybrid methodology utilizing local and regional information (details in Sect. 2.3)
}

of $2.6 \mathrm{~W} \mathrm{~m}^{-2}$ by the end of the century (2100), consistent with the goal of limiting the increase of global average temperature due to human activity to $2{ }^{\circ} \mathrm{C}$. Both RCP scenarios include century-long estimates of air pollutant emissions, including aerosols, and were used as input in the LMDz-INCA global chemistry model.

Present-day emission estimates for the IdF region are available in hourly intervals, with a spatial resolution of $1 \times 1 \mathrm{~km}$. The emission data set was compiled by local experts using a variety of city-specific information integrating a number of anthropogenic activities in the IdF region (AIRPARIF, 2012). The spatial allocation of emissions is completed with proxies such as high-resolution population maps, road network and the location of industrial units. It includes emissions of $\mathrm{CO}, \mathrm{NO}_{\mathrm{x}}$, non-methane volatile organic compounds (NMVOCs), $\mathrm{SO}_{2}, \mathrm{PM}_{10}$ and $\mathrm{PM}_{2.5}$ with a monthly, weekly and diurnal (source specific) temporal resolution. The distribution of emissions among different activity sectors reveals that in the IdF region the principal emitter of $\mathrm{NO}_{\mathrm{x}}$, on annual basis, is the road transport sector $(50 \%)$, for NMVOCs the use of solvents ( $46 \%$ ) and for fine particles the residential sector $(40 \%)$. Annual emissions rates within the simulated decade were kept constant; only the vertical distribution of point source emissions across model layers varies in time since it depends on several meteorological variables such as temperature and wind (plume-rise algorithm) (Scire et al., 1990). Finally, the $1 \mathrm{~km}$ resolution emissions were aggregated to the $4 \mathrm{~km}$ resolution grid.

Mid-21st century (year 2050) emission projections for IdF incorporate local-scale information, including the implementation of planed policies. The short-term component consists of the local scale 2020 emission projection compiled by AIRPARIF in the framework of the Plan de Protection de l'Atmosphere d'Ile de France (PPA) and with the support of the Direction Regionale et Interdepartementale de
l'Environnement et de l'Energie d'Ile de France (DRIEEIF). Emissions for 2020 correspond to a business-as-usual scenario assuming the implementation of all regulatory measures planned by the PPA.

The long-term component of the projection is established by linking two primary sources of information: (i) the aforementioned 2020 AIRPARIF inventory and (ii) a set of scenarios from the recently published Global Energy Assessment (GEA) (Riahi et al., 2012) to extend projections until 2050. The GEA scenarios, while consistent with similar long-term climate outcomes as the RCPs, include a more detailed representation of short-term air-quality legislation from the GAINS model (Amann et al., 2011). Outputs are based on the MESSAGE model (Riahi et al., 2007) and include estimates of energy and greenhouse gas emissions for 11 global regions while air pollutants are also available at $0.5^{\circ} \times 0.5^{\circ}$ resolution estimated based on inventory data described in Granier et al. (2011) and Lamarque et al. (2010) and an exposure-driven algorithm for the downscaling of the regional air-pollutant emission projections. The GEA scenarios have been used to estimate global health impacts of outdoor air pollution (Rao et al., 2012, 2013) as well as for regional impacts analysis (Colette et al., 2012, 2013). Two GEA scenarios are used in our analysis: (i) a reference (REF) scenario (consistent with long-term climate outcomes of the RCP-8.5) which adopts all current and planned air-quality legislation until 2030 and assumes that no climate policies are implemented thereafter (ii) a mitigation (MIT) scenario (consistent with long-term climate outcomes of the RCP-2.6) which additionally assumes stringent climate mitigation policies consistent with a target of $2{ }^{\circ} \mathrm{C}$ global warming by the end of the century (2100). Thus the MIT scenario can be used to assess the co-benefits of climate induced strategies. We derived national-wide annual totals (for France) in 2020 and 2050 for a number of pollutants from the GEA scenarios. 
Table 2. Current time and future emission estimates (kt) over a $50 \mathrm{~km}^{2}$ area around extracted from the 1 st model layer.

\begin{tabular}{llll}
\hline & $\mathrm{NO}_{\mathrm{x}}{ }^{\mathrm{a}}$ & $\mathrm{NMVOCs}^{\mathrm{a}}$ & $\mathrm{PM}_{2.5}{ }^{\mathrm{b}}$ \\
\hline $\mathrm{CTL}$ & 11.2 & 22.6 & 1.5 \\
2050 REF & 3.1 & 10.6 & 0.34 \\
$2050 \mathrm{MIT}$ & 1.0 & 8.1 & 0.18 \\
\hline
\end{tabular}

a Ozone period (April-August).

${ }^{\mathrm{b}}$ Winter period.

The 2050 to 2020 scaling ratios were calculated for each pollutant for each source sector accounted for in the GEA data set. The resulting ratios are used as coefficients to scale the local 2020 AIRPARIF inventory without modifying the spatial and temporal patterns.

We decided to derive scaling ratios based on national totals and not from the GEA $0.5^{\circ}$ resolution grid to avoid adopting the relatively simplistic approaches of the GEA downscaling algorithm for the distribution of emissions at the finer scale. Thus, our approach benefits from the highly resolved emission variability over Paris from the AIRPARIF inventory, but it must be noted that at the same time we inherently assume the energy transition over the 2020 to 2050 period according to the REF and MIT scenarios. This is particularly relevant as the GEA scenarios implement significant improvements in energy efficiency and a complete implementation and continuation of air-quality policies in Europe. Thus we observe significant reductions in emissions for the IdF region in 2050 (Table 2). While using different scenarios would lead to alternative estimates of 2050 emissions, it is important to note that significant technological change in the energy systems would likely mean that air pollutant emissions in Europe would decline over the long term in any case, although the exact distribution of such reductions is uncertain.

\section{Model evaluation based on the control simulation (present-day)}

\subsection{Meteorology}

It is beyond the purpose of this study to provide an in-depth meteorology evaluation; however, to build confidence in the meteorological fields used as input for our air-quality simulations, we present a short model evaluation based on the CTL run.

WRF meteorology for the CTL simulation ran over a $10 \mathrm{~km}$ resolution grid. Model results are compared to surface observations from 7 meteorological stations found inside the IdF region. Only one of these monitors (MONT) is actually inside the city of Paris. The mean wintertime (DJF) and summertime (JJA) modeled and observed daily average values were calculated for four different variables relevant to air quality: $2 \mathrm{~m}$ temperature, wind speed at $10 \mathrm{~m}$, relative hu- midity and total precipitation (Table 3). A warm bias during summer reaches $+0.8^{\circ} \mathrm{C}$ in the city center (MONT station). This is bound to lead to enhanced ozone formation due to the thermal decomposition of peroxyacetyl nitrate-releasing $\mathrm{NO}_{\mathrm{x}}$ (Sillman and Samson, 1995). Modeled wind speeds are higher than the observed ones both during winter and summer, a bias consistent with previous studies (see, for example, Jimenez et al. (2012) for WRF or Vautard et al. (2012) for other models). This is expected to enhance pollutants' dispersion and lead to less frequent stagnation episodes. The model underestimates summertime relative humidity (bias = $-13.3 \%)$. A systematic wet bias in wintertime precipitation is observed in the city reaching $+26.5 \%$. This is expected to lead to underestimation of PM levels through rain scavenging (Fiore et al., 2012).

\section{Ozone concentrations}

Scatter plots in Fig. 2 compare modeled ozone with surface measurements. Mean daytime surface ozone and $\mathrm{O}_{\mathrm{x}}$ $\left(\mathrm{NO}_{2+} \mathrm{O}_{3}\right)$ (averaged over the April-August period) as well as the daily maximum of 8-hour running means (MD8hr) from the urban stations are shown. Modeled daytime ozone is in very good agreement with measurements over the urban cluster with a bias of only $+0.25 \mathrm{ppb}$ ( $0.8 \%$ overestimation). Note that the spread of ozone bias among individual stations is also small. $\mathrm{O}_{\mathrm{x}}$ is often used as an indicator of ozone photochemical build-up because it rules out the titration process. Therefore, the low $\mathrm{O}_{\mathrm{x}}$ bias indicates that local-scale modeling reproduces sufficiently both urban titration (daytime) and photochemical formation. $\mathrm{NO}_{2}$ bias (not shown) is also low $(-0.32 \mathrm{ppb})$. Model results for ozone are considered satisfactory given the nature of these runs (forced by climate simulations and not forecast meteorology as discussed in Sect. 2.2). The MNB (+16.5\%) and MNGE (+40.6\%) are outside but near the US EPA targeted ranges $( \pm 15 \%$ and $+35 \%$, respectively). For downtown Paris sites (not shown), MNB is $+10.9 \%$ and MNGE is equal to $+39.8 \%$. However, the model underestimates MD8hr by $-7.8 \%$ (bias = $-3.2 \mathrm{ppb}$ ). The 95th percentile (not shown) of observed and modeled ozone daily maxima differ by $13.8 \mathrm{ppb}(-20.1 \%)$ indicating that the model fails to reproduce ozone levels under extreme photochemical episodes which in any case are produced in timely short periods of very specific meteorological conditions characterized by stagnated air masses and low vertical mixing favoring ozone build-up. The meteorological input used in our local simulation poorly represents the observed wind speeds, which are overestimated significantly (Sect. 3.1). This affects stagnation (Jacob and Winner, 2009; Vautard et al., 2007) but also vertical diffusivity through an increased boundary layer height. At the same time, the climate model suffers from a cold and overcast bias (Colette et al., 2013) that inhibits the emission of biogenic precursors and ozone buildup. 
Table 3. Observed and modeled meteorological variables over the Ile-de-France region. Modeled data stem from the WRF simulation at $10 \mathrm{~km}$ resolution. Absolute model bias is given in parenthesis. MONT refers to the Montsouris station.

\begin{tabular}{|c|c|c|c|c|}
\hline \multirow[t]{2}{*}{ Variable } & \multicolumn{2}{|c|}{ Summer (JJA) } & \multicolumn{2}{|c|}{ Winter (DJF) } \\
\hline & Obs & Model & Obs & Model \\
\hline \multicolumn{5}{|l|}{ Seven-station average } \\
\hline $\mathrm{T} 2\left({ }^{\circ} \mathrm{C}\right)$ & 19.2 & $19.8(+0.6)$ & 4.3 & $4.2(-0.1)$ \\
\hline $\mathrm{WS} 10\left(\mathrm{~m} \mathrm{~s}^{-1}\right)$ & 2.9 & $3.7(+0.8)$ & 3.6 & $5.5(+1.9)$ \\
\hline $\mathrm{RH}(\%)$ & 69.1 & $55.8(-13.3)$ & 85.0 & $83.9(-1.1)$ \\
\hline PRECIP (mm day ${ }^{-1}$ ) & 0.076 & $0.073(-0.003)$ & 0.07 & $0.094(+0.024)$ \\
\hline \multicolumn{5}{|l|}{ MONT (Paris) } \\
\hline $\mathrm{T} 2\left({ }^{\circ} \mathrm{C}\right)$ & 20.1 & $20.9(+0.8)$ & 5.4 & $4.9(-0.5)$ \\
\hline $\mathrm{WS} 10\left(\mathrm{~m} \mathrm{~s}^{-1}\right)$ & 2.8 & $3.3(+0.5)$ & 3.3 & $4.7(+1.4)$ \\
\hline $\mathrm{RH}(\%)$ & 64.9 & $50.8(-14.1)$ & 79.8 & $79.5(-0.3)$ \\
\hline PRECIP (mm day $\left.{ }^{-1}\right)$ & 0.073 & $0.085(+0.012)$ & 0.064 & $0.081(+0.017)$ \\
\hline
\end{tabular}

Overestimation of mean daytime ozone is observed in all suburban and rural stations $(+10.9 \%$ and $+11.3 \%$, respectively) even though $\mathrm{O}_{\mathrm{x}}$ is in relatively good agreement with measurements. This points to an underestimation of $\mathrm{NO}_{2}$, and titration is represented less faithfully. Ozone overestimation is due, to some extent, to the boundary conditions. This is supported by the fact that both upwind and downwind rural stations show the same level of overestimation portraying a spatially symmetric influence of boundary conditions (not shown). In the urban areas, the strong titration probably depletes the excess of ozone from the boundaries, pointing to a possible exaggeration of urban titration in the model. In general, MNB and MNGE scores for suburban and rural sites (Fig. 2) lie close to but outside the US EPA targeted ranges.

\subsection{Fine particulate matter}

Modeled $\mathrm{PM}_{2.5}$ surface concentrations are compared to all available measurements (i.e., four urban sites, only one of which located in Paris). Results for wintertime (DJF), summertime (JJA) and on annual basis are shown in Fig. 3. The model underestimates $\mathrm{PM}_{2.5}$ by $20 \%$ in wintertime $(-14 \%$ at the Paris site). This underestimation could be attributed to the significant positive bias in modeled precipitation and wind speeds (Sect. 3.1). Another explanation could be that the monthly temporal profiles used to distribute the annual emissions of residential heating are based on mean temperature variations. This could lead to strong underestimation of emissions in wintertime. The analysis of the annual model results yields even higher underestimation for both the Paris site and domain-wide values $(-18.9 \%$ and $-26.6 \%$, respectively). The poorer model performance during summertime suggests a possible underestimation of summertime emissions in the local inventory. Vehicle-induced resuspension of particles might be a significant missing source, especially during the drier summertime months (Schaap et al., 2009 and references therein). $\mathrm{PM}_{2.5}$ underestimation, to some extent, is due to a poor representation of secondary organic aerosol (SOA) in the model (modeled SOA concentrations are $<0.5 \%$ in wintertime and $\sim 1.5 \%$ in summertime). This is a well-known shortcoming of regional CTMs (Simpson et al., 2007; Solazzo et al., 2012; Stern et al., 2007). In particular, Hodzic et al. (2009, 2010) found significant underprediction of observed SOA concentrations modeled with CHIMERE in the framework of the Megacity Initiative: Local and Global Research Observations (MILAGRO) campaign. Modeled meteorology (wind and precipitation overestimation) also contributes to the observed PM underestimation. Nevertheless, wintertime and annual metrics are within the US EPA targeted range (MFB within $\pm 30 \%$ and MFE $<50 \%$ ).

\subsection{Conclusions on model evaluation}

The model is able to represent the main features of the ozone photochemical cycle (ozone formation and titration) over the Ile-de-France region but fails to reproduce high ozone episodes. Urban features of ozone chemistry such as ozone titration are resolved, showing that the emission inventory is realistic. Therefore, this local-scale modeling makes it possible to discern between urban, suburban and rural areas and provides a good representation of both ozone build-up and titration processes. The underestimation of $\mathrm{PM}_{2.5}$ is attributed to errors in modeled meteorology (high precipitation and winds) and possibly to missing emission sources and chemical processes (secondary organic aerosol). 

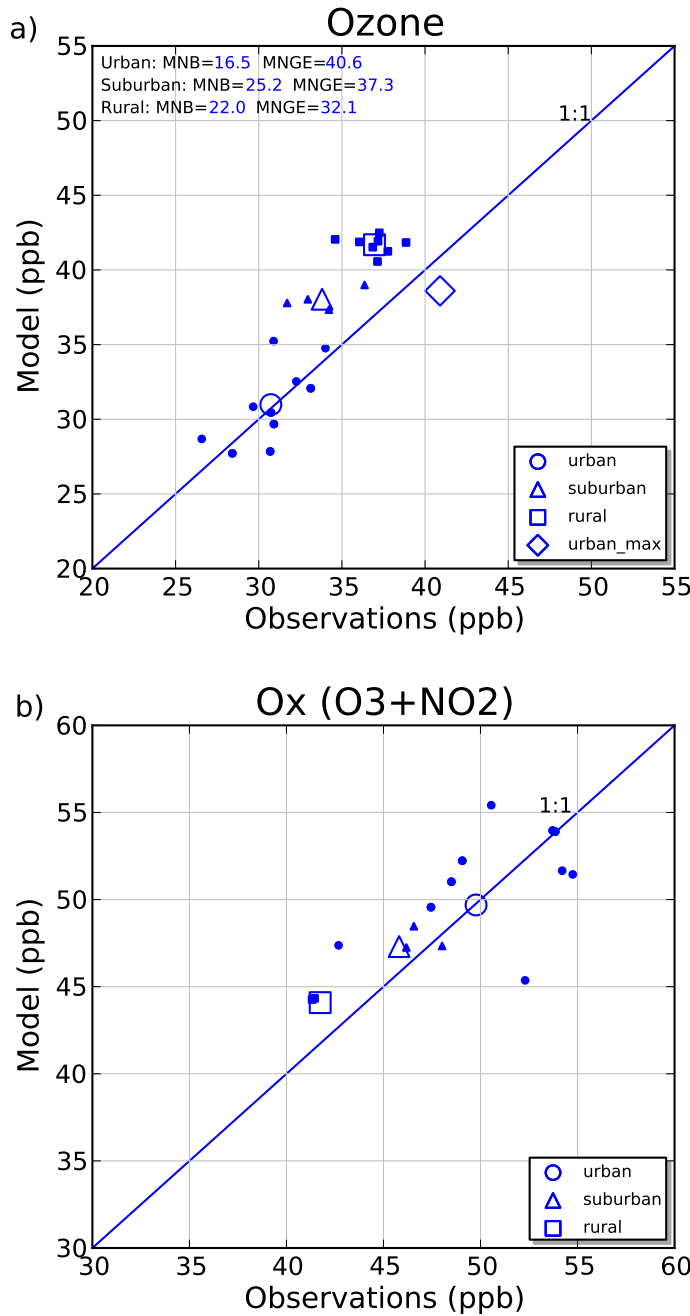

Figure 2. Scatter plots of mean daytime ozone (a) and $\mathrm{O}_{\mathrm{x}}$ (b) during the April to August period from the model run against observations. Small solid markers represent concentrations at individual stations while large hollow markers stand for the aggregated value. "Urban_max" stands for the daily maximum of an $8 \mathrm{hr}$ running average.

Table 4. Future changes in key meteorological variables ${ }^{\mathrm{a}}$ under the two simulated climate scenarios.

\begin{tabular}{llll}
\hline Variable & $\mathrm{CTL}$ & $\Delta(\mathrm{REF}-\mathrm{CTL})$ & $\Delta(\mathrm{MIT}-\mathrm{CTL})$ \\
\hline Temperature $\left({ }^{\circ} \mathrm{C}\right)$ & 11.6 & +1.1 & -0.5 \\
RH $(\%)$ & 72.3 & +1.1 & +1.7 \\
Precipitation $\left(\mathrm{mm} \mathrm{day}^{-1}\right)$ & 0.1 & +0.007 & +0.22 \\
Radiation $\left(\mathrm{W} \mathrm{m}^{-2}\right)$ & 154.3 & -5.4 & -25.4 \\
\hline
\end{tabular}

a Annual domain-wide values extracted from $10 \mathrm{yr}$ mean of daily averages.

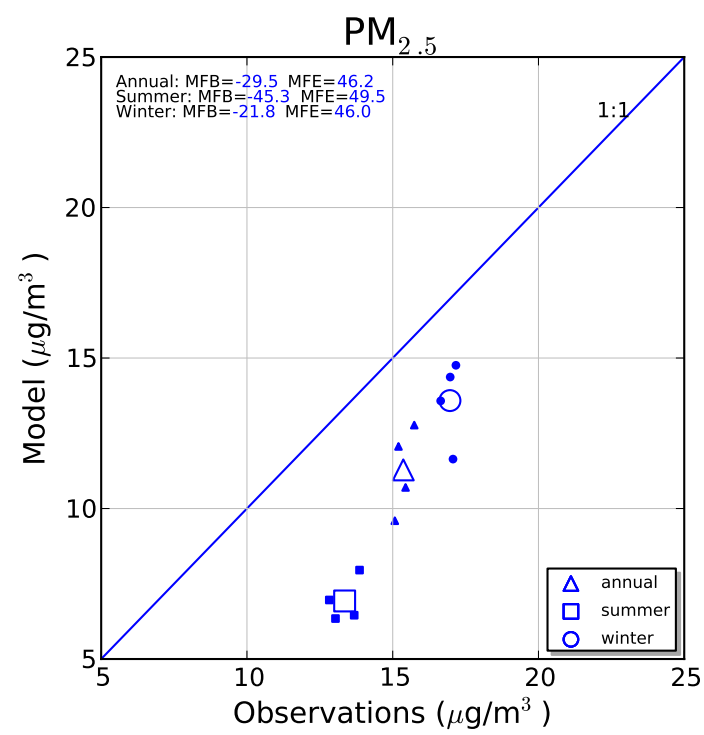

Figure 3. Scatter plot of mean daily $\mathrm{PM}_{2.5}$ from the model run during summer (JJA), winter (DJF) and on annual basis against observations. Small solid markers represent concentrations at individual stations while large hollow markers stand for the aggregated value.

\section{Future scenario analysis}

\subsection{Climate projections for the mid-21st century in Paris}

Table 4 summarizes the projections of key meteorological variables. It is beyond the scope of this study to disentangle the effects of climate and emission changes on air quality and therefore only a brief qualitative discussion is provided in this section.

Under the REF scenario, which assumes that greenhouse gases increase monotonically until the end of the century, the annual mean surface temperatures in the mid-21st horizon exhibits an overall domain-wide increase of $+1.1^{\circ} \mathrm{C}$ $\left(+1.0^{\circ} \mathrm{C}\right.$ over the city) compared to the present-day. Consequently, enhanced ozone formation is expected especially in the rural part of the domain due to the increase of biogenic organic compounds (BVOCs). Monoterpenes are especially sensitive to temperature while isoprene is to both temperature and sunlight. We do not observe any significant changes to shortwave radiation, relative humidity $(\mathrm{RH})$ or precipitation under the REF scenario.

A $-0.5^{\circ} \mathrm{C}$ decrease in the annual surface temperature compared to the present-day is modeled under the MIT trajectory, with two particularly cold years (2051 and 2052) lowering the decade average. The inter-annual variability (standard deviation) is $2.54^{\circ} \mathrm{C}$ around a decade average of $11.3^{\circ} \mathrm{C}$, while under the REF scenario the variability is $0.8^{\circ} \mathrm{C}$ around a decade average of $13^{\circ} \mathrm{C}$. The internal natural variability of temperature can be very large at the regional scale (Deser et al., 2012), which stresses the need for 
longer simulation periods over which the inter-annual variability would be smoothed. Lower temperatures are expected to inhibit ozone formation while the drop of shortwave downward radiation by $16.6 \%$ relative to the present will lead to less BVOCs in the rural areas. We observe a significant increase in total precipitation compared to the control simulation by a factor of 3.2 under the MIT pathway where, similarly to temperature, two particularly wet years (2050 and 2051) are simulated. Modeled precipitation is high only on a limited amount of days within those two years (standard deviation $=0.73$ around a decade average of 0.32 ). In the regional simulation from which boundaries were utilized to force the local runs, the climate is also shown as significantly wetter under MIT by a factor of 3.6.

\section{Ozone projections}

Mid-21st century ozone projections averaged over the April through August period are presented in Fig. 4 for the REF and the MIT scenarios. Panel a shows present-day MD8hr levels (CTL simulation) whereas panels $b$ and $c$ provide differences between each of the REF and MIT scenarios and the CTL simulation. The CTL simulation is able to dissociate the fast ozone titration process from the longer-scale photochemical build-up: low ozone levels are modeled for over the city of Paris (36-38 ppb) due to titration by NO (road transport mainly) and higher levels (47-50 ppb) are modeled for the surrounding rural area due to photochemical formation.

Projections show an increase in maximum ozone $(+7 \mathrm{ppb})$ over the city of Paris under the REF scenario relative to CTL and only a small decrease under the MIT scenario $(-3.5 \mathrm{ppb})$. The average daytime ozone (not shown) also increases substantially in downtown Paris by approximately +10 ppb under REF. The results are consistent with the near future projection of Roustan et al. (2011) who also employed local-scale emissions and modeled maximum ozone increase in Paris for the year 2020. Reductions in rural ozone are modeled under both scenarios: REF: $-3.2 \mathrm{ppb}$ and MIT: $-13.5 \mathrm{ppb}$.

Previous studies have shown that anthropogenic emissions over urban areas are the driver of ozone concentrations compared to climate, boundary conditions and other influencing factors (Colette et al., 2013). Therefore, to gain further insight in the ozone response one should study the differences between present and future ozone precursors' emissions. However emission changes under different chemical regimes may also lead to different ozone responses. For example, air-quality projections conducted at a $0.5^{\circ} \times 0.5^{\circ}$ resolution grid over Europe forced with GEA emissions and the same meteorology as in our study found significant a decrease compared to present-day values in ozone concentrations over the Paris region at the 2050 horizon for both REF ( $-5 \mathrm{ppb})$ and MIT ( $-16 \mathrm{ppb}$ ) scenarios (Colette et al., 2013), in contrast to our findings showing increase in ozone 10yr mean of daily max $\mathrm{O} 3$ concentrations (APR-AUG)

a)

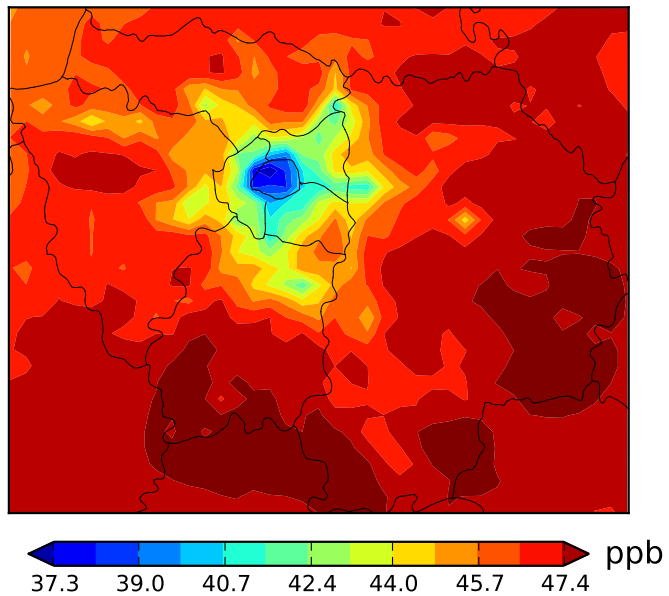

$\Delta(\mathrm{REF}-\mathrm{CTL})$

b)

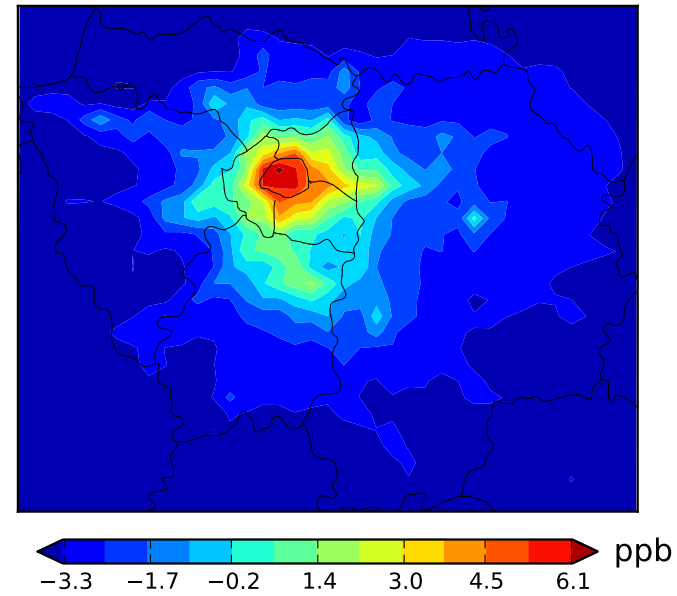

$\Delta(\mathrm{MIT}-\mathrm{CTL})$

C)

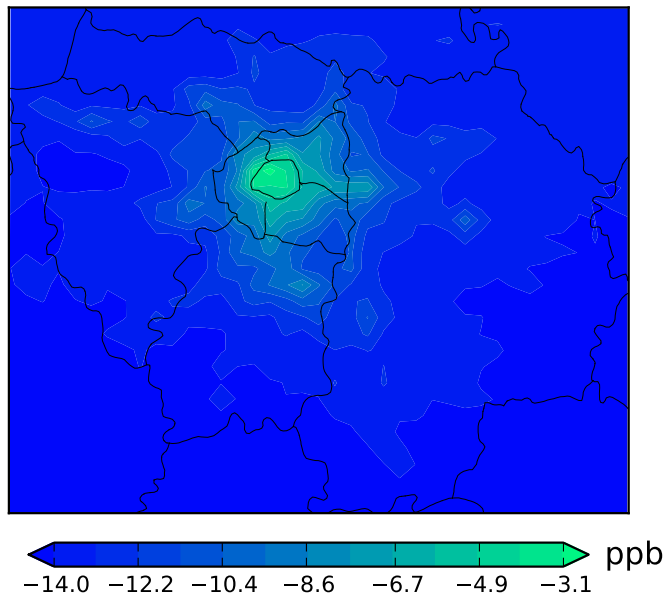

Figure 4. Present-day ozone daily maximum (ppb) of $8 \mathrm{hr}$ running means averaged over the April-August period (a) and differences between the CTL run and the REF (b) and MIT projections (c). 
under the REF scenario and only a small decrease under the MIT scenario. We are interested to see whether this difference in the sign between the local and regional ozone projections could be explained by the photochemical regime under which ozone is produced in each simulation.

\subsection{Analysis of the chemical regimes}

It is known that areas with $\mathrm{NO}_{\mathrm{x}}$ or VOC sensitivity are more effectively mitigated when $\mathrm{NO}_{\mathrm{x}}$ or NMVOCs emission reductions are implemented, respectively (Beekman and Vautard, 2010). Previous modeling exercises using the CHIMERE model have shown that the ozone photochemistry in Paris is VOC sensitive (Beekman and Derognat, 2003; Beekman and Vautard, 2010; Deguillaume et al., 2008).

In this experiment, we perform a model sensitivity analysis in which anthropogenic $\mathrm{NO}_{\mathrm{x}}$ and NMVOCs emissions are allowed to vary from a factor of one-fourth up to two times their actual value with a step of 0.25 (all combinations of 8 different scenarios for both $\mathrm{NO}_{\mathrm{x}}$ and NMVOCs). In total, 64 simulations were performed for a typical summertime ozone episode. Emission changes were applied over the whole 3$\mathrm{D}$ domain. We conducted the same experiment twice: once using as initial local-scale emission inventory developed by AIRPARIF (LOC case) and once using the regional-scale inventory (REG case). In order to isolate the effect of emissions only and exclude the potential impact of other resolutionrelated effects the sensitivity analysis for the REG realization was not performed in the native REG domain; instead, we first downscaled the regional emission inventory on the $4 \mathrm{~km}$ grid and then ran the regional-scale simulation. Obviously, emission totals between the two simulations do not match and no direct comparison should be made based on these results. However, it is interesting to see how different emission starting points may lead to ozone production under different photochemical regimes and therefore to different future ozone projections. We note that present-day $\mathrm{NO}_{\mathrm{x}} / \mathrm{NMVOCs}$ emission ratios within the ozone period over Paris are much higher in the LOC inventory than in the REG data set $(0.5$ vs. 0.2). This ratio is a key factor for the modeling of ozone production. We chose to run the sensitivity analysis over a one-day, present-day, summer ozone episode whose emission fluxes and meteorological conditions, favoring the photochemical ozone build-up, are similar in most ozone events. We also note that while boundary conditions may impact local-scale model predictions, we focus here on the impact of local emissions through the use of a common set of boundary conditions, to ensure that the differences arise from the sensitivity to local emissions.

Isocontours of daily ozone maxima concentrations as a function of $\mathrm{NO}_{\mathrm{x}}$ and NMVOCs emission rates are given for the two simulations (isopleth plots of Fig. 5). Two cases are discussed separately: downtown chemistry (panels a and b) and in-plume chemistry (panels c and d). "In-plume" corresponds to the chemical reactions taking place when high concentrations of nitrous oxides coming from the city and NMVOCs from rural areas help to accumulate ozone on the downwind site of the city. To extract in-plume results we identify, at each hour of the simulated episode, the grid cell with the maximum concentrations inside the domain. Downtown chemistry in the LOC simulation is mainly sensitive to $\mathrm{NO}_{\mathrm{x}}$ changes with sharp ozone increases related to $\mathrm{NO}_{\mathrm{x}}$ reductions. This is a typical ozone response near high $\mathrm{NO}_{\mathrm{x}}$ emission sources where titration and removal of radicals by nitrogen dioxide are the main drivers of ozone concentrations (VOC-sensitive regime). Under the REF scenario $\mathrm{NO}_{\mathrm{x}}$ reductions in 2050 are much more drastic than NMVOC ones (Table 2) because the GEA-derived scaling coefficients used to project local-scale emissions from 2020 to 2050 mainly implement $\mathrm{NO}_{\mathrm{x}}$ reductions through domestic heating and road transport regulation. Under VOC-sensitive conditions, $\mathrm{NO}_{\mathrm{x}}$ reductions without additional regulation of NMVOCs lead to inhibited ozone titration and increase in ozone concentrations. Ozone mitigation would most likely be more effective if the domestic/industrial use of solvents (the main source of NMVOCs) were targeted as well. Under the MIT scenario however, where both $\mathrm{NO}_{\mathrm{x}}$ and NMVOCs are mitigated more effectively than in REF, ozone concentrations decrease in 2050 compared to present-day levels. This feature stands out in the $\mathrm{NO}_{\mathrm{x}}$-limited rural areas in which ozone follows the fate of its precursors showing a much more drastic decrease of ozone under MIT (Fig. 4c) compared to REF (Fig. 4b). On the other hand, chemistry in the REG simulation is driven by a $\mathrm{NO}_{\mathrm{x}}$-sensitive regime. The titration process is much less pronounced compared to the LOC run. As a result, ozone decreases in response to the significant $\mathrm{NO}_{\mathrm{x}}$ reductions (see also discussion in Sect. 2.3) under both REF and MIT scenarios.

In the regional setup, both urban and rural chemistry is characterized by $\mathrm{NO}_{\mathrm{x}}$-sensitive conditions (panel b vs. d). On the contrary, if urban chemistry is clearly VOC sensitive at the local-scale run (panel a), in-plume ozone build-up is found on the ridge line separating the two regimes (panel c). This is consistent with previous studies (Menut et al., 2000; Sillman et al., 2003). Urban ozone levels modeled at the local scale are much lower than those modeled at the regional scale by almost $50 \mathrm{ppb}$ ( $\sim 54 \mathrm{ppb}$ vs. $\sim 100 \mathrm{ppb})$. This is due to the higher $\mathrm{NO}_{\mathrm{x}}$ emission ratios prescribed by the localscale inventory (LOC) compared to the regional inventory (REG). As far as the in-plume chemistry is concerned, the difference between the two simulations is less pronounced $(\sim 20 \mathrm{ppb})$. This is consistent with the fact that the reductions in rural ozone modeled at the regional scale (REF: $-3.2 \mathrm{ppb}$ and MIT: $-13.5 \mathrm{ppb}$ ) and in our study for the two future projections relative to present-day levels are similar. Photochemical ozone build-up occurs at a longer timescale and larger space-scale compared to titration, and therefore the increase in the resolution of the emissions brought about at the local scale does not provide much new information to the modeling of rural ozone. 

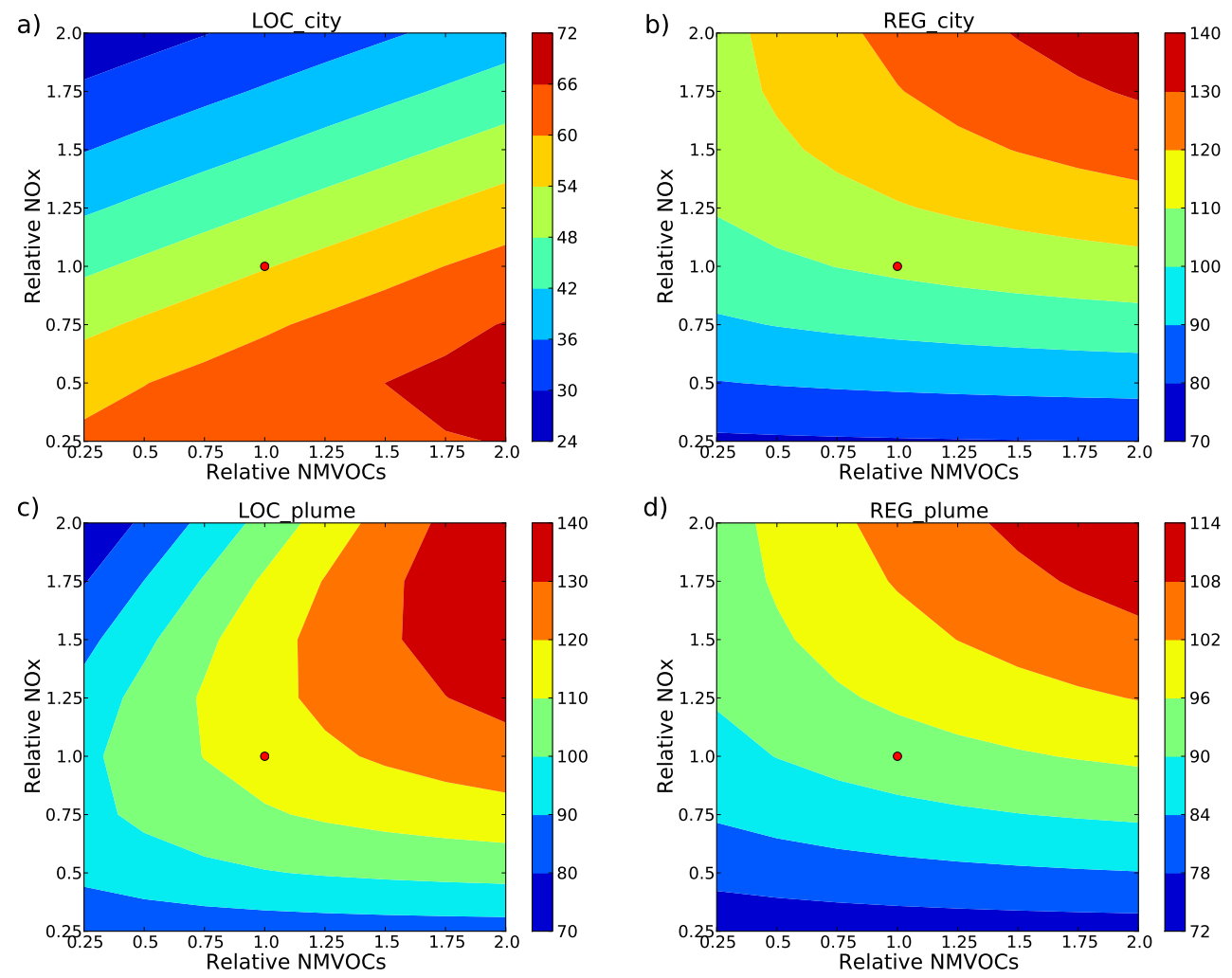

Figure 5. Isocontours of maximum ozone concentrations over downtown Paris (top panels) and over the entire modeling domain (IdF) (bottom panels) as a function of ozone precursor emissions. Axis units are the coefficients of emission changes (in molecules $\mathrm{cm}^{-2} \mathrm{~s}^{-1}$ ) with respect to their baseline values (point 1.0,1.0). Isopleths on the left are modeled with the LOC simulation and on the right with the REG simulation.

This sensitivity analysis shows that the integration of highresolution emission projections in the modeling of ozone is critical. Clearly the regional and local simulation will respond differently to emission changes in the future but unfortunately it is not possible to assess quantitatively the impact of this change since besides the spatial gradients in emissions, projections also differ between the LOC and REG simulations. The conclusion that can be drawn though from this sensitivity analysis is that the simulation forced by the regional-scale emissions fails to distinguish the chemical regime between urban and rural chemistry (both shown as $\mathrm{NO}_{\mathrm{x}}$-limited) and that ozone titration over Paris is most likely underestimated in the regional setup, which may explain the ozone decrease modeled for 2050 over Paris under the REF scenario. Increase in ozone due to sharp $\mathrm{NO}_{\mathrm{x}}$ emission reductions under a VOC-limited environment, as modeled with the local setup, may be more realistic.

\subsection{Future chemical regimes indicators}

Based on the aforementioned previous studies as well as on the sensitivity exercise carried out here, ozone formation in the city of Paris occurs under VOC-sensitive conditions. However, it is plausible that the implementation of emis- sion reductions in the long run causes a shift of the chemical regime towards a more $\mathrm{NO}_{\mathrm{x}}$-sensitive chemistry (Beekman and Vautard, 2010; Colette et al., 2012; Tarasson et al., 2003).

To investigate this shift, we use here a number of chemical regime indicators, which explain emission accumulation and radical production/loss processes: $\mathrm{O}_{3} / \mathrm{NO}_{\mathrm{y}}, \mathrm{O}_{3} / \mathrm{NO}_{\mathrm{z}}$ and $\mathrm{H}_{2} \mathrm{O}_{2} / \mathrm{NO}_{\mathrm{z}}$. Each indicator accounts for different aspects of ozone chemistry, for example the $\mathrm{H}_{2} \mathrm{O}_{2} / \mathrm{NO}_{\mathrm{z}}$ ratio takes into account both the impact of emissions and radical production (Sillman, 1995) by comparing the $\mathrm{HO}_{\mathrm{x}}+\mathrm{NO}_{\mathrm{x}}$ radical sink (yielding $\mathrm{NO}_{\mathrm{z}}$ ) to the $\mathrm{HO}_{2}+\mathrm{HO}$ radical sink yielding $\mathrm{H}_{2} \mathrm{O}_{2}$. The latter sink corresponds to enhanced radical production, which favors $\mathrm{NO}_{\mathrm{x}}$-sensitive conditions (Kleinman, 1997). These indicators are used in order to avoid the large number of sensitivity runs such as the ones described in Sect. 4.2.1 that would be necessary to perform if one used a more direct approach such as above.

Chemical regime indicators are estimated from domainwide daytime $\mathrm{O}_{3}, \mathrm{NO}_{\mathrm{y}}, \mathrm{NO}_{\mathrm{z}}$ and $\mathrm{H}_{2} \mathrm{O}_{2}$ concentrations for the CTL run and the two REF and MIT projections (Fig. 6). Higher $\mathrm{O}_{3} / \mathrm{NO}_{\mathrm{y}}, \mathrm{O}_{3} / \mathrm{NO}_{\mathrm{z}}$ and $\mathrm{H}_{2} \mathrm{O}_{2} / \mathrm{NO}_{\mathrm{z}}$ ratios point to more $\mathrm{NO}_{\mathrm{x}}$-sensitive conditions while lower ratio values point to VOC-sensitive chemistry. A visual inspection of the figure 

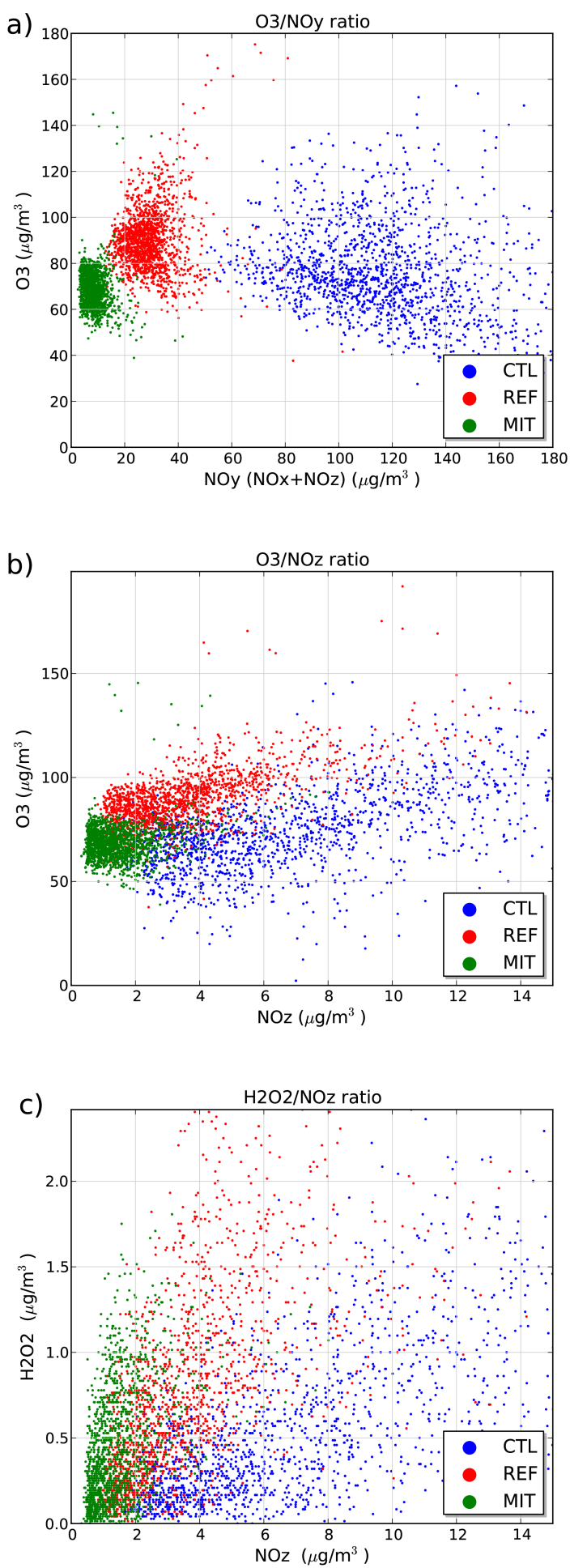

Figure 6. Ozone chemical regime indicators for the control run and the two future projections. Dots represent daily means, averaged during the ozone period over the grid cells of the downtown Paris area.
Table 5. Ozone exposure indicators for the control simulation and the relative differences between the latter and the two future projections for the city of Paris.

\begin{tabular}{llll}
\hline Variable & CTL & REF & MIT \\
\hline City & & & \\
SOMO35 (ppb days) & 13763 & 27470 & 2904 \\
Nd120 (days) & 29 & 18 & - \\
MTDM (ppb) & 53.9 & 54.7 & 39.6 \\
Rural & & & \\
SOMO35 (ppb days) & 39581 & 29101 & 2115 \\
Nd120 (days) & 134 & 4 & - \\
MTDM (ppb) & 63.8 & 52.9 & 38.9 \\
\hline
\end{tabular}

reveals that all three chemical indicator ratios increase under both REF and MIT scenarios compared to CTL due to decreases in $\mathrm{NO}_{\mathrm{y}}$ and $\mathrm{NO}_{\mathrm{z}}$ concentrations induced by the implemented $\mathrm{NO}_{\mathrm{x}}$ emission reductions. For example the decade mean $\mathrm{O}_{3} / \mathrm{NO}_{\mathrm{y}}$ molar ratio shifts from the present-day value of 0.64 to 2.75 and 10.6 in the REF and MIT scenarios, respectively. Based on these indicators we deduce that a shift towards more $\mathrm{NO}_{\mathrm{x}}$-sensitive chemistry should be expected in 2050 under both REF and MIT scenarios.

\subsection{Ozone health indicators}

Here we study how different ozone health indicators change under the two future scenarios (Table 5). We focus on three indexes: (i) the sum of the differences between maximum daily 8 -hour running means and the $35 \mathrm{ppb}$ threshold value (SOMO35); (ii) the number of days where maximum daily 8hour running mean ozone concentration exceeds the $60 \mathrm{ppb}$ threshold (Nd120) and (iii) the mean of the ten highest daily max concentrations during the ozone period (MTDM). These metrics are typically used in health impact assessment studies and account for the non-linearity in the ozone dose-response function. For example SOMO35 was developed in the Joint WHO/Convention Task Force in 2004 and represents the cumulative annual exposure to ozone. The threshold value was established by the fact that a statistically significant increase in mortality risk estimates was observed at ozone concentrations above $25-35 \mathrm{ppb}$.

Under the REF scenario, SOMO35 modeled at the local scale in the city is almost doubled compared to the presentday (Table 5) while the reductions of the $\mathrm{Nd} 120$ index from 29 to 18 days points to less frequent ozone episodes in the future. The MTDM index remains constant, suggesting that ozone episodes will not decrease in intensity.

All three health-related proxies improve under the MIT scenario. SOMO35 decreases by $79 \%$ and MTDM by $26.5 \%$ relative to CTL, corresponding to future conditions with no significant ozone episodes (Nd120 falls to zero). The modeled reductions in the health indicators represent a much more efficient mitigation compared to maximum ozone 
10yr mean of daily avg PM2.5 concentrations (DJF)

a)

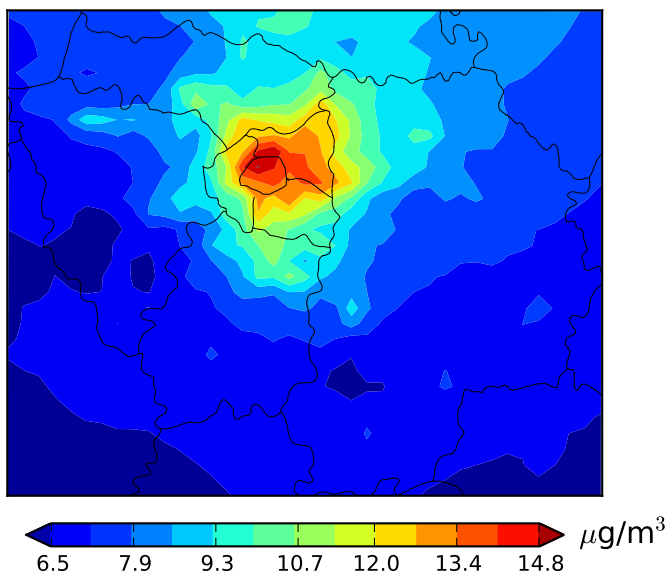

$\Delta(\mathrm{REF}-\mathrm{CTL})$

b)

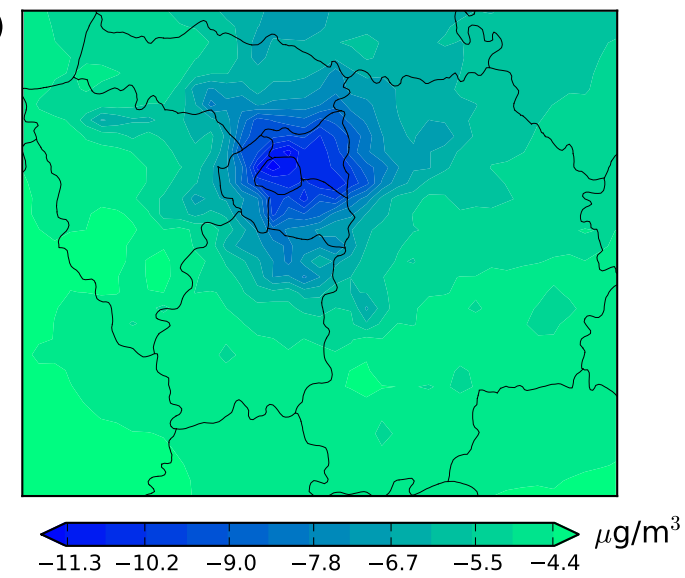

$\Delta(\mathrm{MIT}-\mathrm{CTL})$

C)

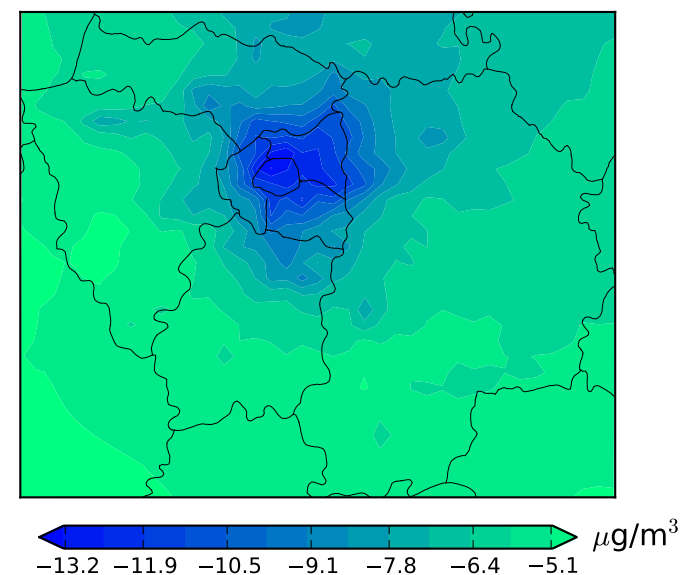

Figure 7. Wintertime (DJF) $\mathrm{PM}_{2.5}$ daily average fields $\left(\mu \mathrm{g} \mathrm{m}^{-3}\right)$ for the control simulation (a) and the differences between the latter and the REF (b) and MIT (c) future projections. concentrations (see discussion in Sect. 4.2) highlighting the high sensitivity of these indicators to their respective cutoff thresholds. It becomes clear that from a human health perspective the MIT scenario is very effective and the cobenefits of climate and air-quality strategies are significant. In the downwind rural areas south of Paris, all health indicators under both scenarios are improved, as seen in Table 5, following the subsiding of ozone levels in the future (Fig. 4).

\section{$9.4 \quad \mathrm{PM}_{2.5}$}

Local-scale $\mathrm{PM}_{2.5}$ projections (wintertime) are presented in Fig. 7 as well as differences between each of the REF and MIT scenarios and the CTL simulation. A major decrease in $\mathrm{PM}_{2.5}$ is modeled under both REF and MIT projections compared to present-day levels. This is mainly due to significant reductions in primary particle emissions (Table 2). In downtown Paris, concentrations are reduced from $14.2 \mu \mathrm{g} \mathrm{m}^{-3}$ in CTL to $3.4 \mu \mathrm{g} \mathrm{m}^{-3}$ and $1.6 \mu \mathrm{g} \mathrm{m}^{-3}$ under the REF and MIT scenarios, respectively. The reductions are much stronger in the city than at rural areas due to the effective mitigation of road transport emissions. Consequently, the large wintertime urban increment (difference between urban and rural concentrations) of approximately $6.8 \mu \mathrm{g} \mathrm{m}^{-3}$ modeled with CTL is significantly reduced in both future projections: $\sim 1 \mu \mathrm{g} \mathrm{m}^{-3}$ in REF and less than $0.2 \mu \mathrm{g} \mathrm{m}^{-3}$ in MIT.

\section{Conclusions}

Mid-21st century ozone and $\mathrm{PM}_{2.5}$ projections for over the city of Paris have been modeled with the CHIMERE airquality model at a $4 \mathrm{~km}$ horizontal resolution under two consistent climate and emission scenarios: a reference and a mitigation scenario. To our knowledge, this is the first time that a study of a 10-year air-quality projection under climate and city-level emission changes is conducted over a large European agglomeration at such fine scale. A key innovation of this work is that we use local-scale emissions and their projections until 2020 developed by local experts (AIRPARIF) and extend those until 2050 based on coefficients extracted from large-scale emission projections. A 10-year control simulation served model evaluation purposes. Furthermore, we investigate how ozone projections under the two future scenarios depend on the photochemical regime.

Model evaluation showed a very good agreement between model and measurements for ozone and an underestimation of wintertime $\mathrm{PM}_{2.5}$ by $20 \%$ over the urban area, which is mainly attributed to a large wet bias in wintertime precipitation $(+26.5 \%)$. The comparison between modeled and measured $\mathrm{O}_{\mathrm{x}}$ showed that the model at $4 \mathrm{~km}$ resolution accurately resolves $\mathrm{O}_{3}$ titration by $\mathrm{NO}$ over the highly urbanized city of Paris. The decade-average bias within the ozone period for $\mathrm{O}_{\mathrm{x}}\left(\mathrm{O}_{3}+\mathrm{NO}_{2}\right)$ and ozone is found to be less that $0.3 \mathrm{ppb}$. 
Under the reference scenario, ozone increases over the city of Paris by $+7 \mathrm{ppb}$ relative to present-day values and only a small decrease is modeled under the mitigation scenario $(-3.5 \mathrm{ppb})$. Through a sensitivity analysis, we showed that ozone formation in Paris occurs under VOC-sensitive chemistry. Under such conditions and due to the stronger mitigation of $\mathrm{NO}_{\mathrm{x}}$ compared to NMVOCs in the REF scenario, titration is inhibited and ozone increases in the 2050 horizon. Following the MIT trajectory, both $\mathrm{NO}_{\mathrm{x}}$ and NMVOCs are more effectively regulated, leading to ozone reduction in 2050. The same sensitivity analysis applied on the regional emission projections showed that ozone formation in Paris occurred under $\mathrm{NO}_{\mathrm{x}}$-sensitive conditions. The discrepancy in the chemical regime is attributed to differences in ozone precursor emissions prescribed by the two inventories: $\mathrm{NO}_{\mathrm{x}} / \mathrm{NMVOCs}$ emission ratios are much lower in the regional (0.2) compared to the local inventory (0.5). Modeling at the regional scale most likely underestimates ozone titration, prescribing $\mathrm{NO}_{\mathrm{x}}$-limited chemistry for Paris. Under this chemical regime, ozone precursor emission cutbacks prescribed even for the less-optimistic REF scenario benefits ozone air quality to such an extent that reductions are observed, while the local setup yields ozone increases instead. If the regional-scale model is inadequate to resolve urban features of ozone chemistry, mainly titration close to high $\mathrm{NO}_{\mathrm{x}}$ emission sources, it yields similar rural ozone levels as the local-scale run, showing that the longer timescale processes of emission transport and ozone formation are less sensitive to model resolution in the high ozone concentration plume. Our findings suggest that the estimates based on Europeanscale applications are likely to overestimate the downward ozone trend under VOC-sensitive conditions while differences in rural areas are limited.

Finally, in downtown Paris, $\mathrm{PM}_{2.5}$ concentrations are reduced by $78 \%$ and $89 \%$ under the REF and MIT scenarios, respectively. The reduction is much more prominent over the urban part of the domain due to significant reductions in primary emissions as a result of the effective mitigation of road transport and residential sector emissions. Therefore, the large urban increment modeled in the control run is significantly reduced in both future projections.

Acknowledgements. The project is funded by the GIS-Climat, the French Environment and Energy Management Agency, ADEME, contract no. $1110 \mathrm{C} 0073$.

Edited by: J. West

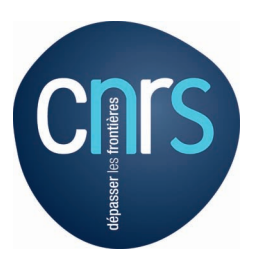

The publication of this article is financed by CNRS-INSU.

\section{References}

AIRPARIF: Evaluation Prospective des emissions et des concentrations des pollutants atmospheriques a l'horizon 2020 en IleDe-France - Gain sur les emissions en 2015, available at: http:// www.airparif.asso.fr/_pdf/publications/ppa-rapport-121119.pdf (last access: 7 May 2013), 2012.

Amann, M., Bertok, I., Borken-Kleefeld, J., Cofala, J., Heyes, C., Höglund-Isaksson, L., Klimont, Z., Nguyen, B., Posch, M., Rafaj, P., Sandler, R., Schöpp, W., Wagner, F., and Winiwarter, W.: Cost-effective control of air quality and greenhouse gases in Europe: modeling and policy applications, Environ. Modell. Softw., 26, 1489-1501, 2011.

Arunachalam, S., Holland, A., Do, B., and Abraczinskas, M.: A quantitative assessment of the influence of grid resolution on predictions of future-year air quality in North Carolina, USA, Atmos. Environ., 40, 5010-5026, 2006.

Beekman, M. and Derognat, C.: Monte Carlo uncertainty analysis of a regional-scale transport chemistry model constrained by measurements from the Atmospheric Pollution Over the Paris Area (ESQUIF) campaign, J. Geophys. Res., 108, 8559, doi:10.1029/2003JD003391, 2003.

Beekmann, M. and Vautard, R.: A modelling study of photochemical regimes over Europe: robustness and variability, Atmos. Chem. Phys., 10, 10067-10084, doi:10.5194/acp-1010067-2010, 2010.

Bessagnet B., Seigneur, C., and Menut, L. Impact of dry deposition of semi-volatile organic compounds on secondary organic aerosols, Atmos. Environ., 44, 1781-1787, 2010.

Brasseur, G. P., Jeffrey, T. K., Muller, J.-F., Schneider, T., Granier, C., Tie, X., and Hauglustaine, D.: Past and future changes in global tropospheric ozone: impact and radiative forcing, Geophys. Res. Lett., 25, 3807-3810, 1998.

Butler, T. M., Stock, Z. S., Russo, M. R., Denier van der Gon, H. A. C., and Lawrence, M. G.: Megacity ozone air quality under four alternative future scenarios, Atmos. Chem. Phys., 12, 4413-4428, doi:10.5194/acp-12-4413-2012, 2012.

Chen, F. and Dudhia, J.: Coupling an advanced landsurface/hydrology model with the Penn State/NCAR MM5 modeling system, Part I: model description and implementation, Mon. Weather Rev., 129, 569-585, 2001.

Cohan, D. S., Hu, Y., and Russell, A. G.: Dependence of ozone sensitivity analysis on grid resolution, Atmos. Environ., 40, 126135, 2006.

Colette, A., Granier, C., Hodnebrog, Ø., Jakobs, H., Maurizi, A., Nyiri, A., Rao, S., Amann, M., Bessagnet, B., D’Angiola, A., Gauss, M., Heyes, C., Klimont, Z., Meleux, F., Memmesheimer, M., Mieville, A., Rouïl, L., Russo, F., Schucht, S., Simpson, D., Stordal, F., Tampieri, F., and Vrac, M.: Future air quality in Europe: a multi-model assessment of projected exposure to ozone, Atmos. Chem. Phys., 12, 1061310630, doi:10.5194/acp-12-10613-2012, 2012.

Colette, A., Bessagnet, B., Vautard, R., Szopa, S., Rao, S., Schucht, S., Klimont, Z., Menut, L., Clain, G., Meleux, F., Curci, G., and Rouil, L.: European atmosphere in 2050, a regional air quality and climate perspective under CMIP5 scenarios, Atmos. Chem. Phys., 13, 7451-7471, doi:10.5194/acp-137451-2013, 2013. 
Deguillaume, L., Beekmann, M., and Derognat, C.: Uncertainty evaluation of ozone production and its sensitivity to emission changes over the Ile-de-France region during summer periods, J. Geophys. Res., 113, D02304, doi:10.1029/2007JD009081, 2008.

Deser, C., Phillips, A., Bourdette, V., and Teng, H. Y.: Uncertainty in climate change projections: the role of internal variability, Clim. Dynam., 38, 527-546, 2012.

Dudhia, J.: Numerical study of convection observed during the winter monsoon experiment using a mesoscale two-dimensional model, J. Atmos. Sci., 46, 3077-3107, 1989.

Dufresne, J.-L., Foujols, M.-A., Denvil, S., Caubel, A., Marti, O., Aumont, O., Balkanski, Y., Bekki, S., Bellenger, H., Benshila, R., Bony, S., Bopp, L., Braconnot, P., Brockmann, P., Cadule, P., Cheruy, F., Codron, F., Cozic, A., Cugnet, D., de Noblet, N., Duvel, J.-P Ethé, C., Fairhead, L., Fichefet, T., Flavoni, S., Friedlingstein, P., Grandpeix, J.-Y., Guez, L., Guilyardi, E., Hauglustaine, D., Hourdin, F., Idelkadi, A., Ghattas, J., Joussaume, S., Kageyama, M., Krinner, G., Labetoulle, S., Lahellec, A., Lefebvre, M.-P., Lefevre, F., Levy, C., Li, Z. X., Lloyd, J., Lott, J., Madec, G., Mancip, M., Marchand, M., Masson, S., Meurdesoif, Y., Mignot, J., Musat, I., Parouty, S., Polcher, J., Rio, C., Schulz, M., Swingedouw, D., Szopa, S., Talandier, C., Terray, P., Viovy, N., and Vuichard, N. Climate change projections using the IPSL-CM5 Earth System Model: from CMIP3 to CMIP5, Clim. Dynam., 40, 2123-2165, 2013.

EPA: Guidance on the Use of Models and Other Analyses for Demonstrating Attainment of Air Quality Goals for Ozone, $\mathrm{PM}_{2.5}$ and Regional Haze, EPA-454/B-07-002, Research Triangle Park, North Carolina, April 2007.

Fiore, A. M., Naik, V., Spracklen, D. V., Steiner, A., Unger, N., Prather, M., Bergmann, D., Cameron-Smith, P. J., Cionni, I., Collins, W. J., Dalsøren, S., Eyring, V., Folberth, G. A., Ginoux, P., Horowitz, L. W., Josse, B., Lamarque, J.-F., MacKenzie, I. A., Nagashima, T., O’Connor, F. O., Righi, M., Rumbold, S. T., Shindell, D. T., Skeie, R. B., Sudo, K., Szopa, S., Takemura, T., and Zeng, G.: Global air quality and climate, Chem. Soc. Rev., 41, 6663-6683, 2012.

Forkel, R. and Knoche, R.: Regional climate change and its impact on photooxidant concentrations in southern Germany: simulations with a coupled regional climate-chemistry model, J. Geophys. Res., 111, D12302, doi:10.1029/2005JD006748, 2006.

Forkel, R. and Knoche, R.: Nested regional climate-chemistry simulations for central Europe, CR Geosci., 339, 734-746, 2007.

GEA: Global Energy Assessment - Toward a Sustainable Future, Chapter 17: Energy Pathways for Sustainable Development, Cambridge University Press, Cambridge, UK and New York, NY, USA and the International Institute for Applied Systems Analysis, Laxenburg, Austria, available at: http://www.iiasa.ac.at/web/home/research/Flagship-Projects/ Global-Energy-Assessment/HomeGEA.en.html, 2012.

Granier, C., Bessagnet, B., Bond, T., D’Angiola, A., Denier Van Der Gon, H., Frost, G., Heil, A., Kaiser, J., Kinne, S., Klimont, Z., Kloster, S., Lamarque, J.-F., Liousse, C., Masui, T., Meleux, F., Mieville, A., Ohara, T., Raut, J.-C., Riahi, K., Schultz, M., Smith, S., Thompson, A., Van Aardenne, J., Van Der Werf, G., and Van Vuuren, D.: Evolution of anthropogenic and biomass burning emissions of air pollutants at global and regional scales during the 1980-2010 period, Climatic Change, 109, 163-190, 2011.
Guenther, A., Karl, T., Harley, P., Wiedinmyer, C., Palmer, P. I., and Geron, C.: Estimates of global terrestrial isoprene emissions using MEGAN (Model of Emissions of Gases and Aerosols from Nature), Atmos. Chem. Phys., 6, 3181-3210, doi:10.5194/acp-63181-2006, 2006.

Hauglustaine, D. A., Hourdin, F., Jourdain, L., Filiberti, M.A., Walters, S, Lamarque, J. F., and Holland, E. A.: Interactive chemistry in the Laboratoire de Meteorologie Dynamique general circulation model: description and background tropospheric chemistry evaluation, J. Geophys. Res., 190, D04314, doi:10.1029/2003JD003957, 2004.

Hauglustaine, D. A., Balkanski, Y., and Schulz, M.: A global model simulation of present and future nitrate aerosols and their direct radiative forcing of climate, Atmos. Chem. Phys. Discuss., 14, 6863-6949, doi:10.5194/acpd-14-6863-2014, 2014.

Hodzic, A., Vautard, R., Bessagnet, B., Lattuati, M., and Moreto, F.: On the quality of long-term urban particulate matter simulation with the CHIMERE model, Atmos. Environ., 39, 5851-5864. 2005.

Hodzic, A., Jimenez, J. L., Madronich, S., Canagaratna, M. R., DeCarlo, P. F., Kleinman, L., and Fast, J.: Modeling organic aerosols in a megacity: potential contribution of semi-volatile and intermediate volatility primary organic compounds to secondary organic aerosol formation, Atmos. Chem. Phys., 10, 5491-5514, doi:10.5194/acp-10-5491-2010, 2010.

Hogrefe, C., Lynn, B., Civerolo, K., Ku, J.-Y., Rosenthal, J., Rosenzweig, C., Goldberg, R., Gaffin, S., Knowlton, K., and Kinney, P. L.: Simulating changes in regional air pollution over the eastern United States due to changes in global and regional climate and emissions, J. Geophys. Res., 109, D22301, doi:10.1029/2004JD004690, 2004.

Hong, S.-Y. and Lim, J.-O.: The WRF Single-Moment 6-Class Microphysics Scheme (WSM6), J. Korean Meteor. Soc., 42, 129$151,2006$.

Huszar P., Juda-Rezler, K., Halenka, T., Chervenkov, H., Syrakov, D., Krueger, B.C., Zanis, P., Melas, D., Katragkou, E., Reizer, M., Trapp, W. and Belda, M.: Effects of climate change on ozone and particulate matter over Central and Eastern Europe, Clim. Res., 50, 51-68, doi:10.3354/cr01036, 2011.

Intergovernmental Panel on Climate Change: Climate change 2001: the Scientific Basis, Contribution of Working Group I to the Third Assessment Report of the IPCC, Cambridge University Press, Cambridge, UK, and New York, USA, available at: http: //www.ipcc.ch (last access: 20 March 2013), 2001.

Intergovernmental Panel on Climate Change (IPCC): Climate change 2007: the Physical Science Basis, Contribution of Working Group I to the Fourth Assessment Report of the IPCC, available at: http://www.ipcc.ch (last access: 20 March 2013), 2007.

Jacob, D. J. and Winner, D. A.: Effect of climate change on air quality, Atmos. Environ., 43, 51-63, 2009.

Jimenez, P. A. and Dudhia, J.: Improving the representation of resolved and unresolved topographic effects on surface wind in the WRF Model, J. Appl. Meteorol. Clim., 51, 300-316, 2012.

Kain, J. S.: The Kain-Fritsch convective parameterization: an update, J. Appl. Meteorol., 43, 170-181, 2004.

Katragkou E., Zanis, P., Kioutsioukis, I., Tegoulias, I., Melas, D., Krüger, B. C., and Coppola, E.: Future climate change impacts on summer surface ozone from regional climate-air qual- 
ity simulations over Europe, J. Geophys. Res., 116, D22307, doi:10.1029/2011JD015899, 2011.

Kelly, J., Makar, P. A., and Plummer, D. A.: Projections of mid-century summer air-quality for North America: effects of changes in climate and precursor emissions, Atmos. Chem. Phys., 12, 5367-5390, doi:10.5194/acp-12-5367-2012, 2012.

Kleinman, L. I., Daum, P. H., Lee, J. H., Lee, Y.-N., Nunnermacker, L. J., Springston, S. R., Newman, L., Weinstein-Lloyd, J., and Sillman, S.: Dependence of ozone production on NO and hydro-carbons in the troposphere, Geophys. Res. Lett., 24, 2299 2302, 1997.

Knowlton, K., Rosenthal, J. E., Hogrefe, C., Lynn, B., Gaffin, S., Goldberg, R., Rosenzweig, C., Civerolo, K., Ku, J.-Y., and Kinney, P. L.: Assessing ozone-related health impacts under a changing climate, Environ. Health Persp., 112, 1557-1563, 2004.

Lam, Y. F., Fu, J. S., Wu, S., and Mickley, L. J.: Impacts of future climate change and effects of biogenic emissions on surface ozone and particulate matter concentrations in the United States, Atmos. Chem. Phys., 11, 4789-4806, doi:10.5194/acp-11-47892011, 2011.

Lamarque, J.-F., Bond, T. C., Eyring, V., Granier, C., Heil, A., Klimont, Z., Lee, D., Liousse, C., Mieville, A., Owen, B., Schultz, M. G., Shindell, D., Smith, S. J., Stehfest, E., Van Aardenne, J., Cooper, O. R., Kainuma, M., Mahowald, N., McConnell, J. R., Naik, V., Riahi, K., and van Vuuren, D. P.: Historical (1850-2000) gridded anthropogenic and biomass burning emissions of reactive gases and aerosols: methodology and application, Atmos. Chem. Phys., 10, 7017-7039, doi:10.5194/acp10-7017-2010, 2010.

Langner, J., Bergstrom, R., and Foltescu, V.: Impact of climate change on surface ozone and deposition of sulphur and nitrogen in Europe, Atmos. Environ., 39, 1129-1141, 2005.

Langner, J., Engardt, M., Baklanov, A., Christensen, J. H., Gauss, M., Geels, C., Hedegaard, G. B., Nuterman, R., Simpson, D., Soares, J., Sofiev, M., Wind, P., and Zakey, A.: A multi-model study of impacts of climate change on surface ozone in Europe, Atmos. Chem. Phys., 12, 10423-10440, doi:10.5194/acp-12-10423-2012, 2012.

Lattuati, M.: Contribution a l'etude du bilan de l'ozone tropospherique a l'interface de l'Europe et de l'Atlantique Nord: modelisation lagrangienne et mesures en altitude, Phd thesis, Universite P. M. Curie, Paris, France, 1997.

Leroyer, S., Bélair, S., Husain, S. Z., and Mailhot, J.: Sub-Kilometer Numerical Weather Prediction in an Urban Coastal Area: A Case Study over the Vancouver Metropolitan Area, App. Met. and Clim., doi:10.1175/JAMC-D-13-0202-2013, 2014.

Liao, H., Chen, W.-T., and Seinfeld, J. H.: Role of climate change in global predictions of future tropospheric ozone and aerosols, J. Geophys. Res., 111, D11302, doi:10.1029/2005JD006862, 2006.

Markakis, K., Poupkou, A., Melas, D., and Zerefos, C.: A GIS based methodology for the compilation of an anthropogenic $\mathrm{PM}_{10}$ emission inventory in Greece, Atmos. Poll. Res., 1, 71-81, 2010.

Markakis, K., Im, U., Unal, A., Melas, D., Yenigün, O., and İncecik, S.: Compilation of a GIS based high spatially and temporally resolved emission inventory for the Istanbul Greater Area, Atmos. Poll. Res., 3, 112-125, 2012.

Menut, L., Coll, I., and Cautenet, S.: Impact of meteorological data resolution on the forecasted ozone concentrations during the ESCOMPTE IOP2a and IOP2b, Atmos. Res., 74, 139-159, 2005a.
Menut, L., Schmechtig, C., and Marticorena, V.: Sensitivity of the sandblasting fluxes calculations to the soil size distribution accuracy, J. Atmos. Ocean. Technol., 22, 1875-1884, 2005b.

Menut, L., Bessagnet, B., Khvorostyanov, D., Beekmann, M., Blond, N., Colette, A., Coll, I., Curci, G., Foret, G., Hodzic, A., Mailler, S., Meleux, F., Monge, J.-L., Pison, I., Siour, G., Turquety, S., Valari, M., Vautard, R., and Vivanco, M. G.: CHIMERE 2013: a model for regional atmospheric composition modelling, Geosci. Model Dev., 6, 981-1028, doi:10.5194/gmd6-981-2013, 2013.

Mlawer, E. J., Taubman, S. J., Brown, P. D., Iacono, M. J., and Clough, S. A.: Radiative transfer for inhomogeneous atmospheres: RRTM, a validated correlated-k model for the longwave, J. Geophys. Res., 102, 16663-16682, 1997.

Nenes, A., Pilinis, C., and Pandis, S.: ISORROPIA: A new thermodynamic model for inorganic multicomponent atmospheric aerosols, Aquatic Geochem., 4, 123-152, 1998.

Nolte, C. G., Gilliland, A. B., Hogrefe, C., and Mickley, L. J.: Linking global to regional models to assess future climate impacts on surface ozone levels in the United States, J. Geophys. Res., 113, D14307, doi:10.1029/2007JD008497, 2008.

Pleim, J. E.: A combined local and nonlocal closure model for the atmospheric boundary layer, Part I: Model description and testing, J. Appl. Meteorol. Clim., 46, 1383-1395, 2007.

Prather, M., Gauss, M., Berntsen, T., Isaksen, I., Sundet, J., Bey, I., Brasseur, G., Dentener, F., Derwent, R., Stevenson, D., Grenfell, L., Hauglustaine, D., Horowitz, L., Jacob, D., Mickley, L., Lawrence, M., von Kuhlmann, R., Muller, J.-F., Pitari, G., Rogers, H., Johnson, M., van Weele, M., and Wild, O.: Fresh air in the 21st century?, Geophys. Res. Lett., 30, 1100, doi:10.1029/2002GL016285, 2003.

Rao, S., Chirkov, V., Dentener, F., Van Dingenen, R., Pachauri, S., Purohit, P., Amann, M., Heyes, C., Kinney, K., Kolp, P., Klimont, Z., Riahi, K., and Schoepp, W.: Environmental modeling and methods for estimation of the global health impacts of air pollution, Environ. Model. Assess., 17, 613-622, 2012.

Rao, S., Pachauri, S., Dentener, F., Kinney, P., Klimont, Z., Riahi, K., and Schöpp, W.: Better air for better health: forging synergies in policies for energy access, climate change and air pollution, Global Environ. Change, 23, 1122-1130, doi:10.1016/j.gloenvcha.2013.05.003, 2013.

Riahi, K., Gruebler, A., and Nakicenovic, N.: Scenarios of longterm socio-economic and environmental development under climate stabilization, Technol. Forecast. Soc., 74, 887-935, 2007.

Riahi, K., Rao, S., Krey, V., Cho, C., Chirkov, V., Fischer, G., Kindermann, G., Nakicenovic, N., and Rafaj, P.: RCP 8.5 - a scenario of comparatively high greenhouse gas emissions, Climatic Change, 109, 33-57, 2011

Riahi, K., Dentener, F., Gielen, D., Grubler, A., Jewell, J., Klimont, Z., Krey, V., McCollum, D., Pachauri, S., Rao, S., van Ruijven, B., van Vuuren, D. P., and Wilson, C.: Energy pathways for sustainable development, in: Global Energy Assessment: Toward a Sustainable Future, edited by: Nakicenovic, N., IIASA, Laxenburg, Austria and Cambridge University Press, Cambridge, UK and New York, NY, http:/www.iiasa.ac.at/web/home/research/Flagship-Projects/ Global-Energy-Assessment/HomeGEA.en.html, last access: 17 June 2013, 2012. 
Roustan, Y., Pausader, M., and Seigneur, C.: Estimating the effect of on-road vehicle emission control on future air quality in Paris, France, Atmos. Environ., 45, 6828-6836, 2011.

Schaap, M., Manders, A. M. M., Hendriks, E. C. J., Cnossen, J. M., Segers, A. J. S., Denier van der Gon, H. A. C., Jozwicka, M., Sauter, F. J., Velders, G. J. M., Matthijsen, J., and Builtjes, P. J. H.: Regional modelling of particulate matter for the Netherlands, available at: www.pbl.nl (last access: 30 March 2013), 2009.

Scire, J. S., Strimaitis, D. G., and Yamartino, R. J.: Model Formulation and User's Guide for the CALPUFF Dispersion Model, Sigma Research Corp., Concord, MA, 1990.

Sillman, S., Logan, J. A., and Wofsy, S. C.: A regional scale model for ozone in the United States with subgrid representation of urban and power plant plumes, J. Geophys. Res., 95, 5731-5748, 1990.

Sillman, S.: The use of $\mathrm{NO}_{y}, \mathrm{H}_{2} \mathrm{O}_{2}$, and $\mathrm{HNO}_{3}$ as indicators for ozone- $\mathrm{NO}_{\mathrm{x}}$-hydrocarbon sensitivity in urban locations, J. Geophys. Res., 100, 14175-14188, 1995.

Sillman, S. and Samson, F. L.: Impact of temperature on oxidant photochemistry in urban, polluted rural and remote environments, J. Geophys. Res., 100, 11497-11508, 1995.

Sillman, S., Vautard, R., Menut, L., and Kley, D.: O3-NOXVOC sensitivity and NOX-VOC indicators in Paris: Results from models and Atompheric Pollution over the Paris Area (ESQUIF) measurements, J. Geophys. Res., 108, 8563, doi:10.1029/2002JD001561, 2003.

Skamarock, W. C. and Klemp, J. B.: A time-split non-hydrostatic atmospheric model, J. Comput. Phys., 227, 3465-3485, 2008.

Simpson, D. W., Yttri, K., Klimont, Z., Caseiro, A., Gelencser, A., Pio, C., Puxbaum, H., and Legrand, M. R.: Modelling carbonaceous aerosol over Europe: analysis of the CARBOSOL and EMEP EC/OC campaigns, J. Geophys. Res., 112, D23S19, doi:10.1029/2006JD008158, 2007.

Solazzo, E., Bianconi, R., Pirovano, G., Volker, M., Vautard, R., Appel, K. W., Bessagnet, B., Brandt, J., Christensen, J. H., Chemel, C., Coll, I., Ferreira, J., Forkel, R., Francis, X. V., Grell, G., Grossi, P., Hansen, A., Miranda, A. I., Moran, M. D., Nopmongcol, U., Parnk, M., Sartelet, K. N., Schaap, M., Silver, J. D., Sokhi, R. S., Vira, J., Werhahn, J., Wolke, R., Yarwood, G., Zhang, J., Rao, S. T., and Galmarini, S.: Operational model evaluation for particulate matter in Europe and North America in the context of the AQMEII project, Atmos. Environ., 53, 75-92, 2012a.

Solazzo, E., Bianconi, R., Vautard, R., Appel, W., Moran, M. D., Hogrefe, C., Bessagnet, B., Brandt, J., Christensen, J. H., Chemel, C., Coll, I., van der Gon, H. D., Ferreira, J., Forkel, R., Francis, X. V., Grell, G., Grossi, P., Hansen, A., Jericevic, A., Kraljevic, L., Miranda, A.I., Nopmongcol, U., Pirovano, G., Prank, M., Riccio, A., Sarteket, K. N., Schaap, M., Silver, J. D., Sokhi, R. S., Vira, J., Werhahn, J., Wolke, R., Yarwood, G., Zhang, J., Rao, S. T., and Galmarini, S.: Model evaluation and ensemble modeling for surface-level ozone in Europe and North America, Atmos. Environ., 53, 60-74, 2012b.

Stern, R., Builtjes, P., Schaap, M., Timmermans, R., Vautard, R., Hodzic, A., Memmesheimer, M., Feldmann, H., Renner, E., Wolke, R., and Kerschbaumer, A.: A model inter-comparison study focusing on episodes with elevated $\mathrm{PM}_{10}$ concentrations, Atmos. Environ., 42, 4567-4588, 2008.
Szopa, S. and Hauglustaine, D.: Relative impacts of worldwide tropospheric ozone changes and regional emission modifications on European surface-ozone levels, CR Geosci., 339, 709-720, 2007.

Szopa, S., Hauglustaine, D. A., Vautard, R., and Menut, L.: Future global tropospheric ozone changes and impact on European air quality, Geophys. Res. Lett., 33, L14805, doi:10.1029/2006GL025860, 2006.

Szopa, S., Balkanski, Y., Schulz, M., Bekki, S., Cugnet, D., Fortems-Cheiney, A., Turquety, S., Cozic, A., Deandreis, C., Hauglustaine, D., Idelkadi, A., Lathiere, J., Lefevre, F., Marchand, M., Vuolo, R., Yan, N., and Dufresne, J.-L.: Aerosol and ozone changes as forcing for climate evolution between 1850 and 2100, Clim. Dynam., 40, 2223-2250, 2013.

Tagaris, E., Liao, K.-J., DeLucia, A. J., Deck, L., Amar, P., and Russell, A. G.: Potential impact of climate change on air pollutionrelated human health effects, Environ. Sci. Technol., 43, 49794988, 2009.

Tarasson, L., Jonson, J. E., Fagerli, H., Benedictow, A., Wind, P., Simpson, D., and Klein, H.: Transboundary Acidification and Eutrophication and Ground Level Ozone in Europe: SourceReceptor Relationships, Norw. Meteorol. Inst, Oslo, 2003.

Tie, X., Brasseur, G., and Ying, Z.: Impact of model resolution on chemical ozone formation in Mexico City: application of the WRF-Chem model, Atmos. Chem. Phys., 10, 8983-8995, doi:10.5194/acp-10-8983-2010, 2010.

UNFPA: State of World Population 2007: Unleashing the Potential of Urban Growth, 2007.

Valari, M. and Menut, L.: Does an increase in air quality models' resolution bring surface ozone concentrations closer to reality?, J. Atmos. Ocean. Tech., 25, 1955-1968, 2008.

Valari, M., Menut, L., and Chatignoux, E.: Using a chemistry transport model to account for the spatial variability of exposure concentrations in epidemiologic air pollution studies, J. Air Waste Manage., 61, 164-179, 2011.

Valin, L. C., Russell, A. R., Hudman, R. C., and Cohen, R. C.: Effects of model resolution on the interpretation of satellite $\mathrm{NO}_{2}$ observations, Atmos. Chem. Phys., 11, 11647-11655, doi:10.5194/acp-11-11647-2011, 2011.

Vautard, R., Bessagnet, B., Chin, M., and Menut, L.: On the contribution of natural Aeolian sources to particulate matter concentrations in Europe: testing hypotheses with a modelling approach, Atmos. Environ., 39, 3291-3303, 2005.

Vautard, R., Builtjes, P. H. J., Thunis, P., Cuvelier, C., Bedogni, M., Bessagnet, B., Honore, C., Moussiopoulos, N., Pirovano, G., Schaap, M., Stern, R., Tarasson, L., and Wind, P.: Evaluation and intercomparison of Ozone and $\mathrm{PM}_{10}$ simulations by several chemistry transport models over four European cities within the CityDelta project, Atmos. Environ., 41, 173-188, 2007.

Vautard, R., Moran, M. D., Solazzo, E., Gilliam, R. C., Matthias, V., Bianconi, R., Chemel, C., Ferreira, J., Geyer, B., Hansen, A. B., Jericevic, A., Prank, M., Segers, A., Silver, J. D., Werhahn, J., Wolke, R., Rao, S. T., and Galmarini, S.: Evaluation of the meteorological forcing used for the Air Quality Model Evaluation InternationaI Initiative (AQMEII) air quality simulations, Atmos. Environ., V38, P2803, doi:10.1016/j.atmosenv.2011.10.065, 2012. 
van Aardenne, J. A., Dentener, F. J., Olivier, J. G. J., Goldewijk, C. G. M. K., and Lelieveld, J.: A 1 degrees $\times 1$ degrees resolution data set of historical anthropogenic trace gas emissions for the period 1890-1990, Global Biogeochem. Cy., 15, 909-928, 2001. van Vuuren, D., Edmonds, J., Kainuma, M., Riahi, K., Thomson, A., Hibbard, K., Hurtt, G., Kram, T., Krey, V., Lamarque, J. F., Ma-sui, T., Meinshausen, M., Nakicenovic, N., Smith, S., and Rose, S.: The representative concentration pathways: an overview, Clim. Change, 109, 5-31, 2011. 